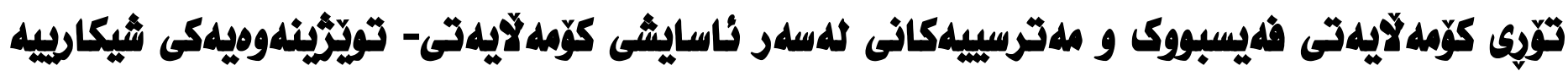

\section{هيّمن ئهمين جهلال شوانى}

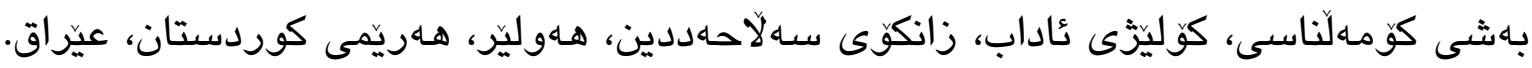

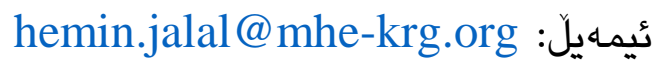

طاهر حسوّ زيبِارى

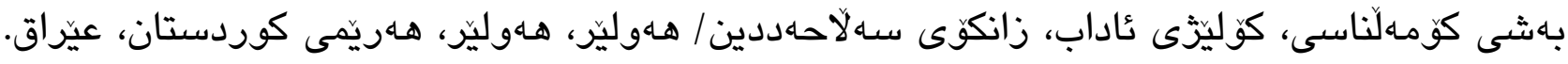

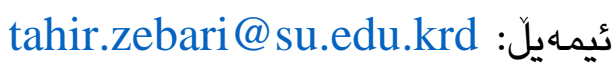

يوخته:

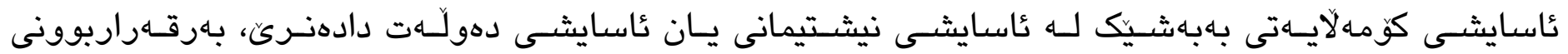

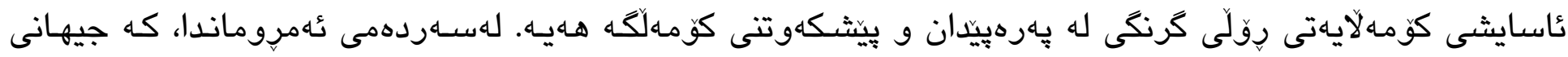

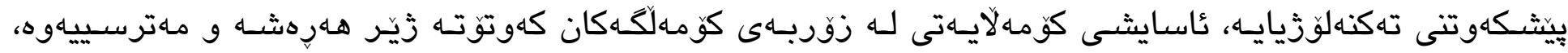

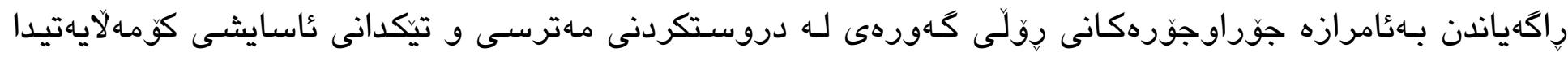

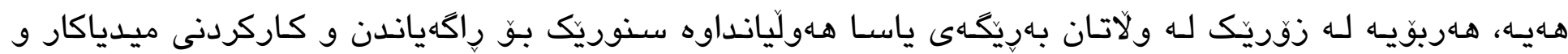

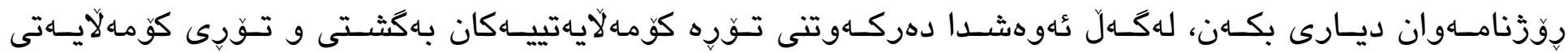

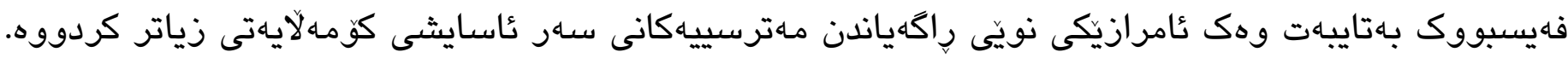

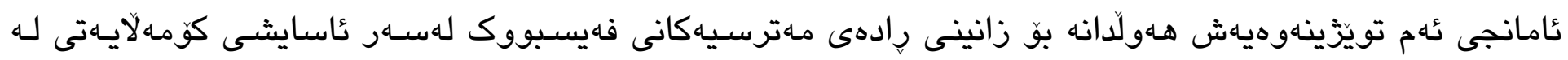

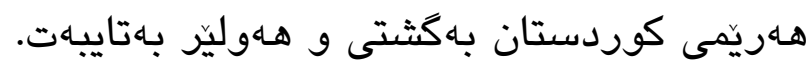

$$
\text { كليله وشُهكان: تقريى كومهالاّيهتى، فهيسبووك، مهترسى، عاسايشى كوّمهلايهتى. }
$$




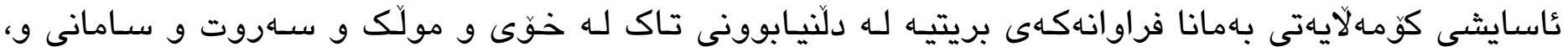

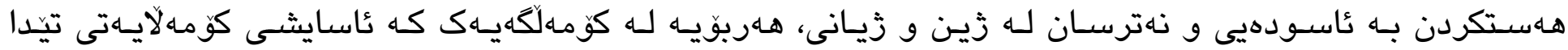

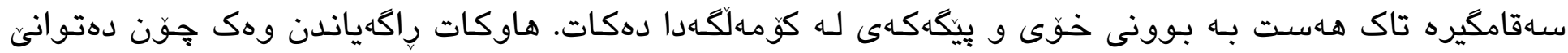

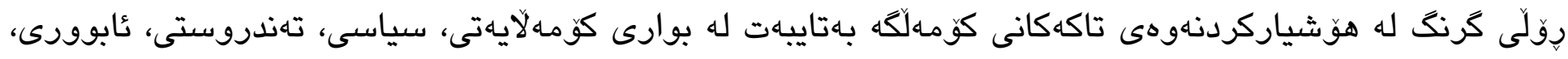

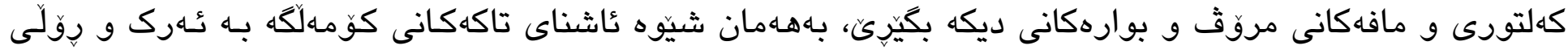

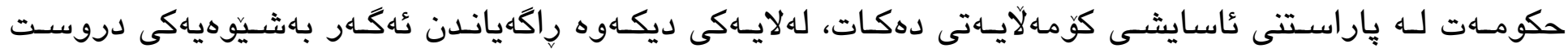

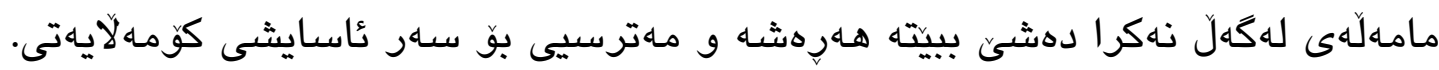

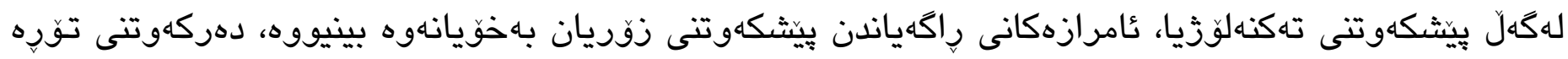

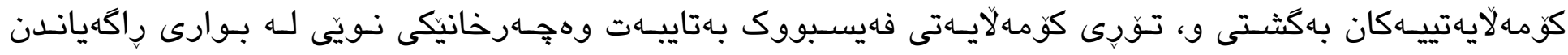

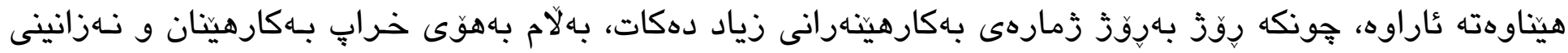

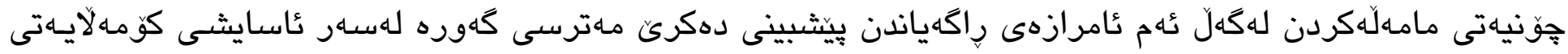
كؤمهالكَكان دروست بكات.

له كوردستان، تا رادهيهك هـولَدراوه به باشه سوود له فهيسبووك وهك ئامرازيّكى نويّى راكَهاندن وهريكيريّ،

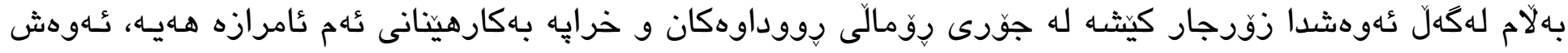

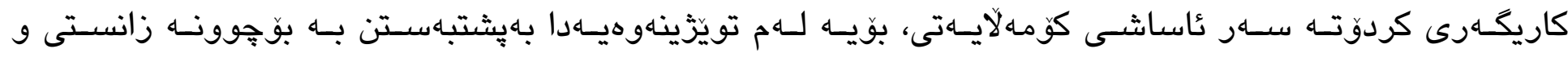

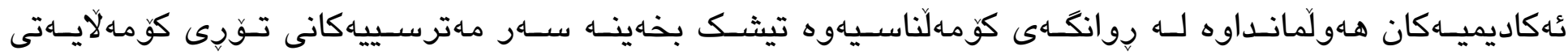

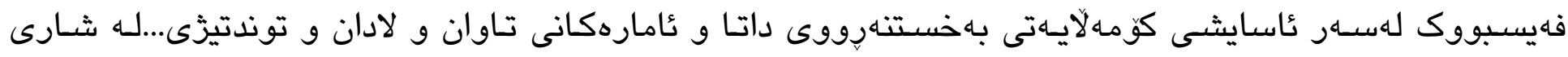
هـاوليّر.

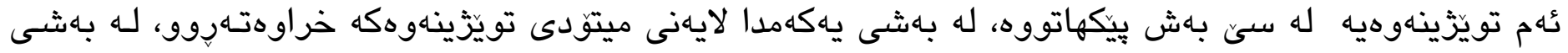
دووهمدا لايهنى تيورى تويَزينهوهكه خراوته بهرباس، كه تيدا بـاس لـه فهيسبووك و لايهنهانى كراوه، هـهروهك لـه

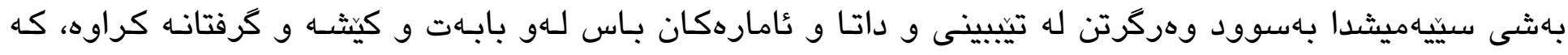
بلأوكردنهوهيان له فهيسبووك مهترسى زياترى لهسهر تيكدانى ئاسايشى كومهالآيهتى دروستكردوه. 


\section{بلاشى يلمكلم}

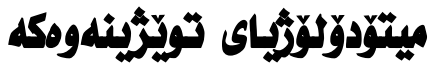

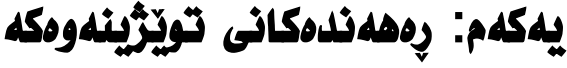

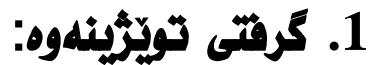

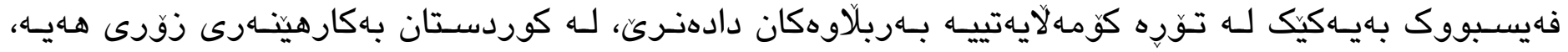

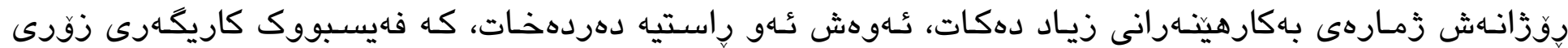

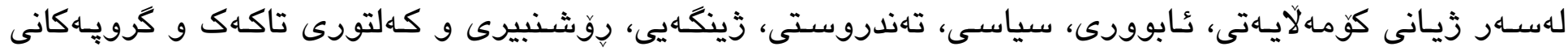

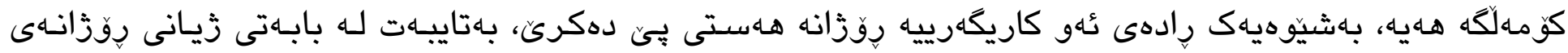

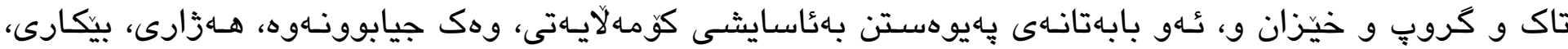
لادان و تاوان...هتد.

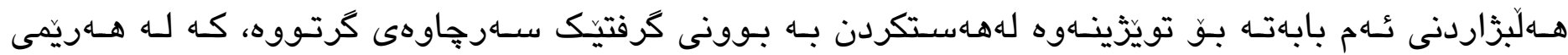

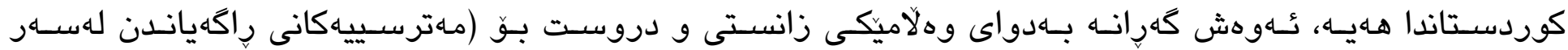

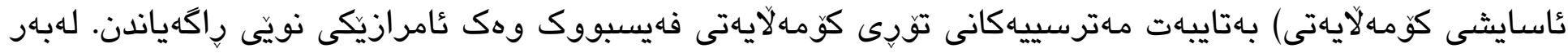

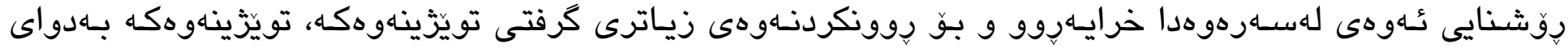
وهلامى ئهم دوو برسياره سهرهكيهدا دهكَريّ:

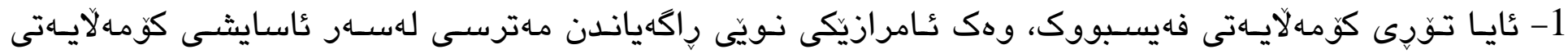
دروستكردووه؟

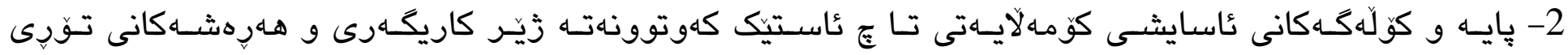
كومهالايهتى فهيسبووك؟

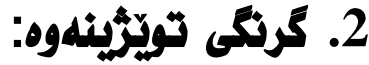

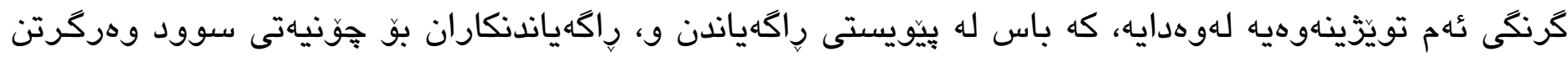

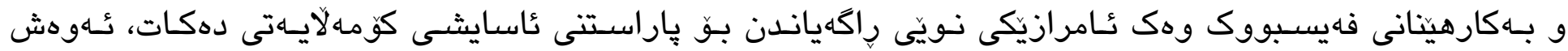

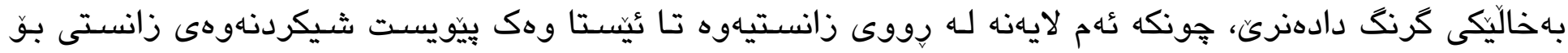

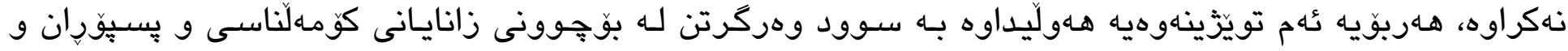

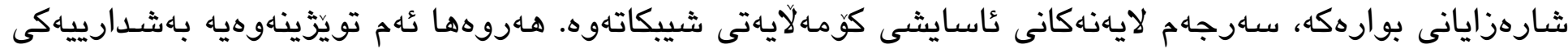




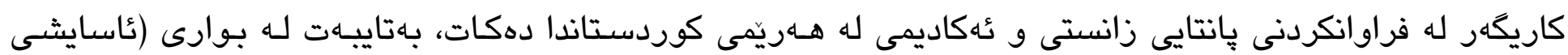

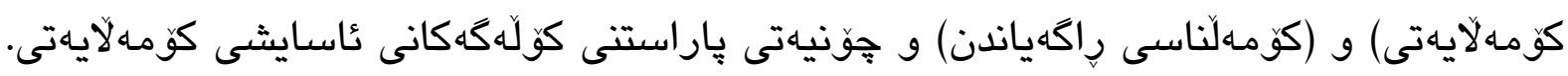

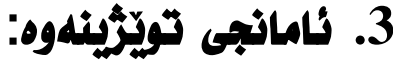

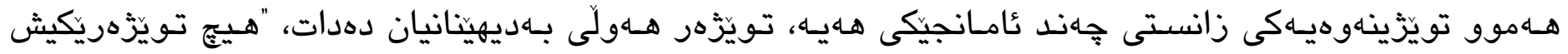

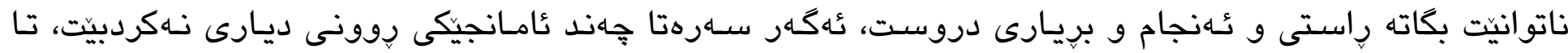

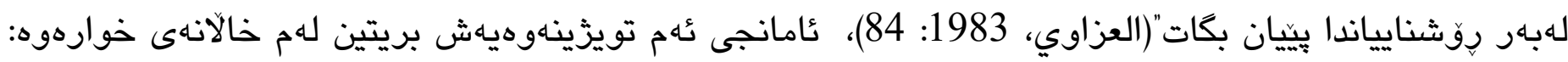

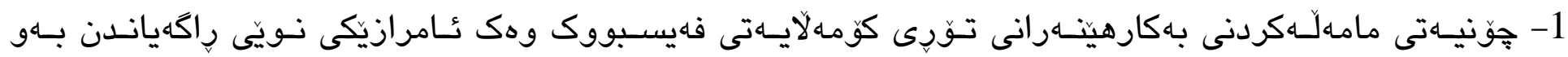

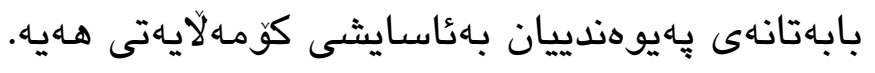

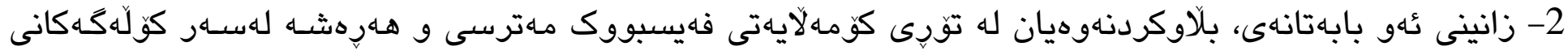

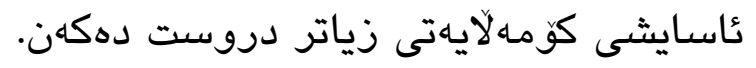

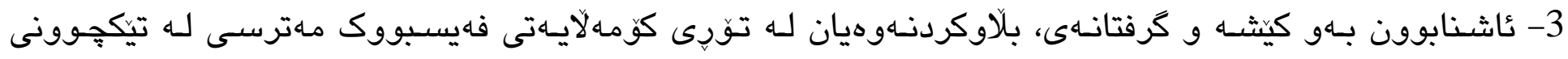
ئاسايشى كوّمالاياهتى دهكهن.

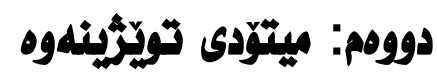

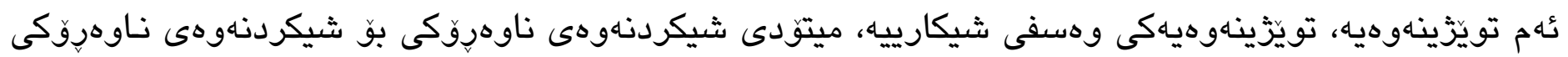

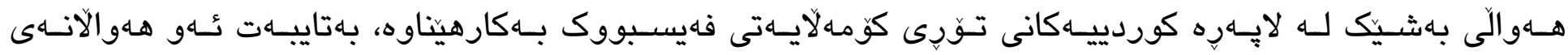

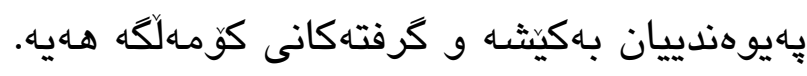

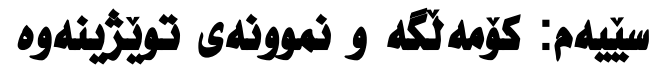

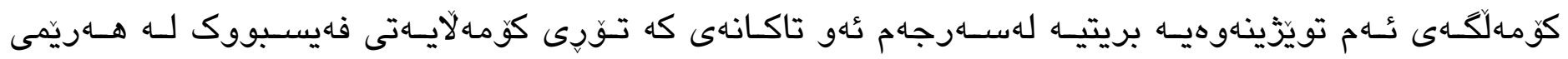

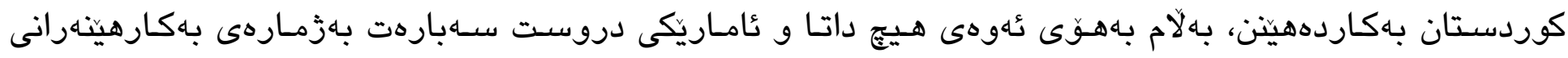

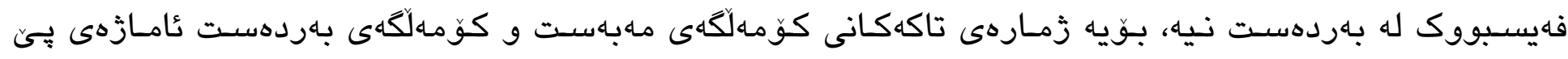

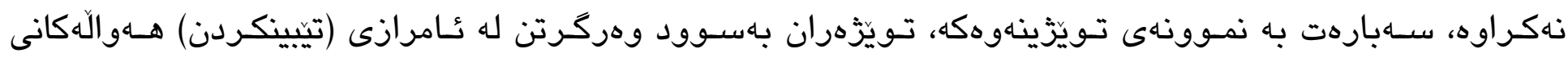
تايبهت به(لادان، تاوان، كوشتن، توندوتيزى خيزّانى، مـاددهى هوشبهر، زيانى تايبهت..هتد)، كه له ماوهى نووسينى

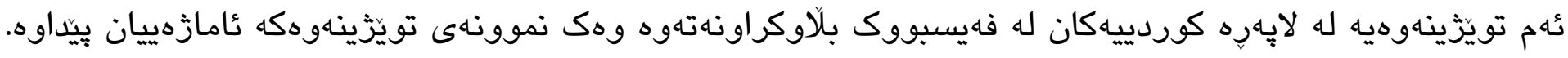




\section{هوارم: بوارهكانى تويَّرينهوه:-}

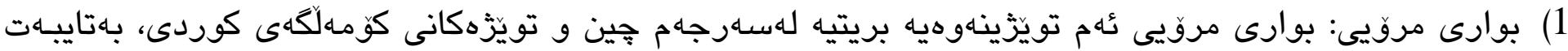

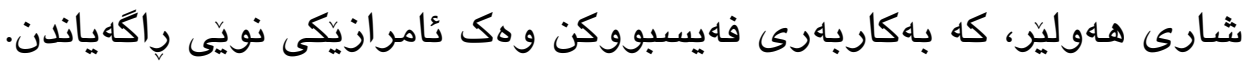

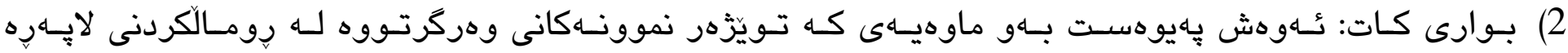

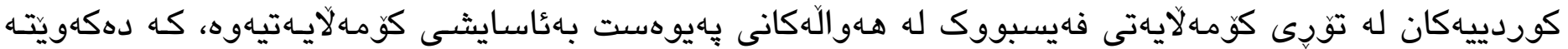
نيّوان (2019/4/16) تاوهكو (2020/5/13).

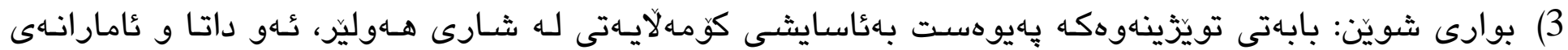

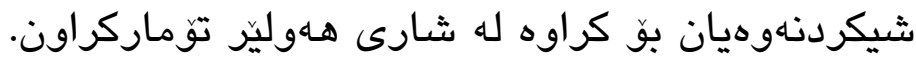

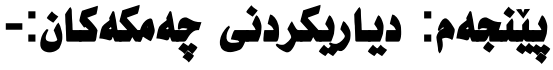

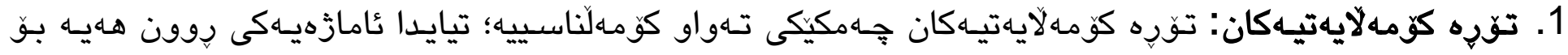

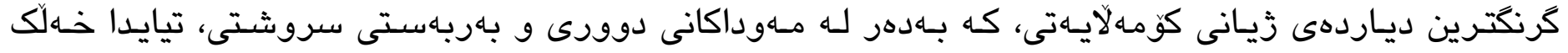

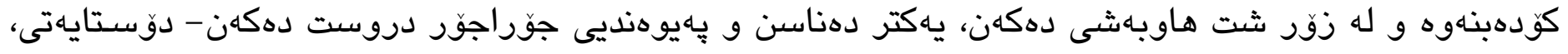

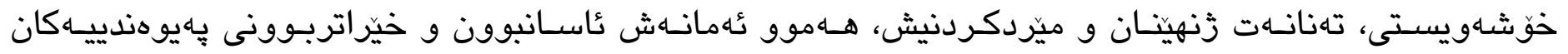

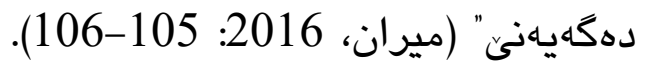

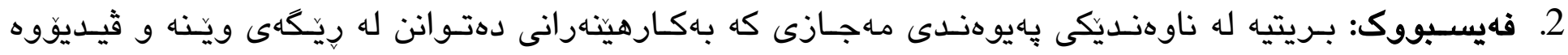

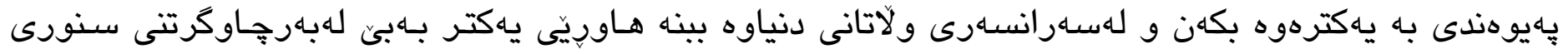

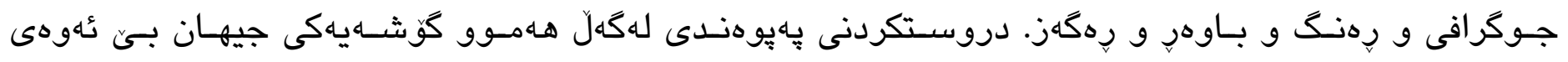

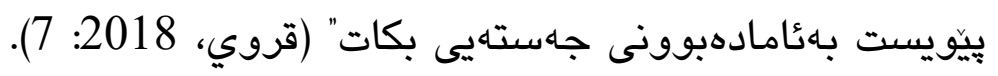

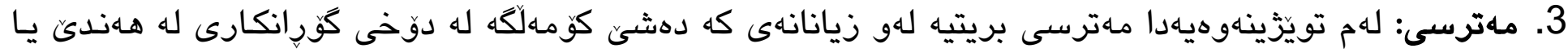

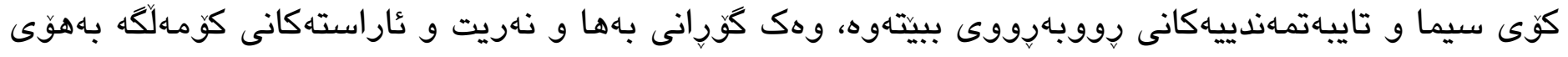

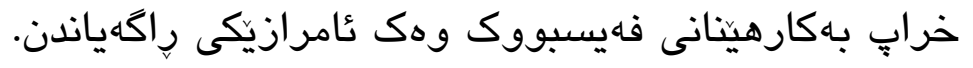

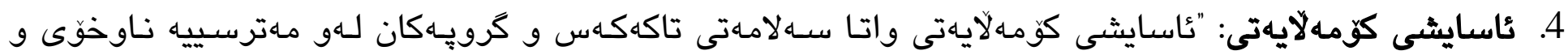

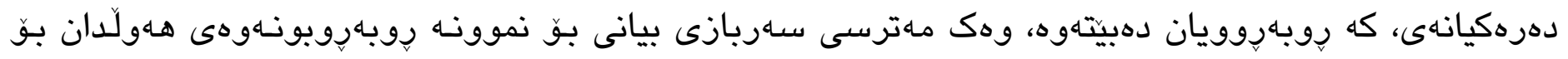

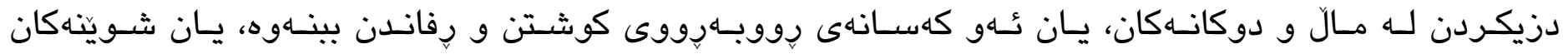




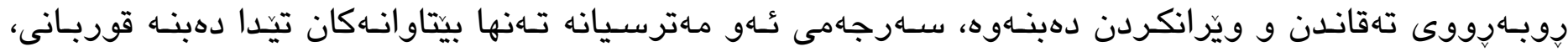

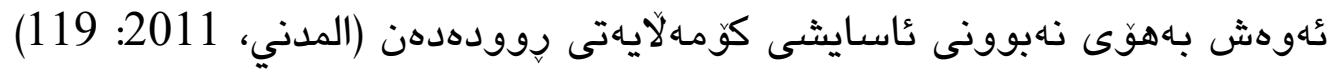

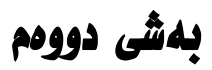

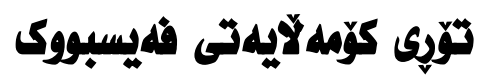

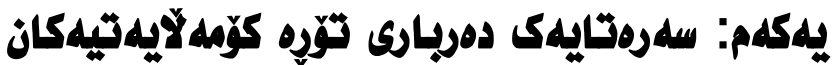

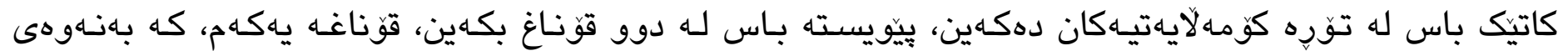

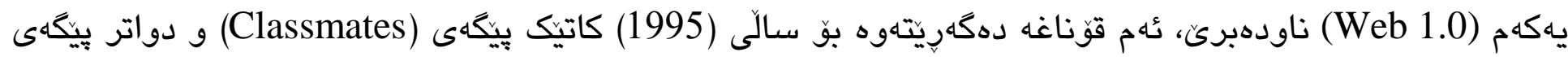

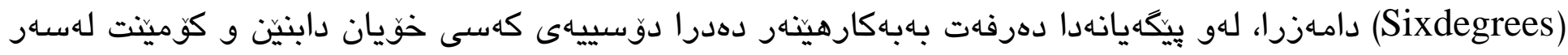

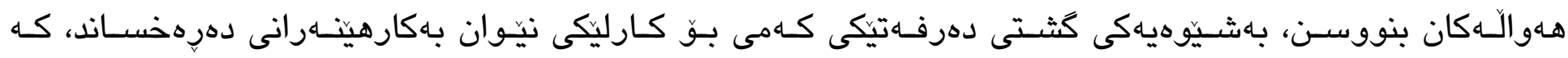

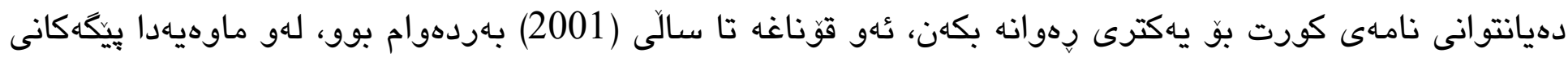
(Asian Avenue ،Black Planet ،Live Journal)

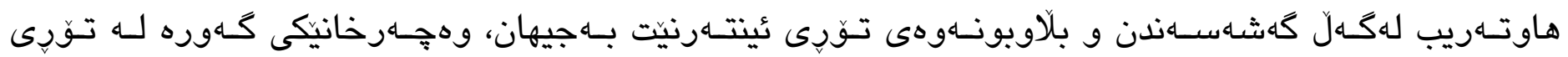

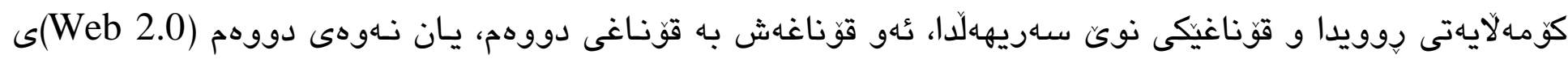

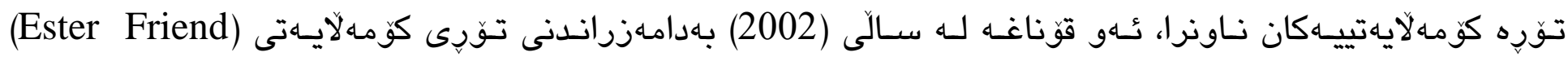

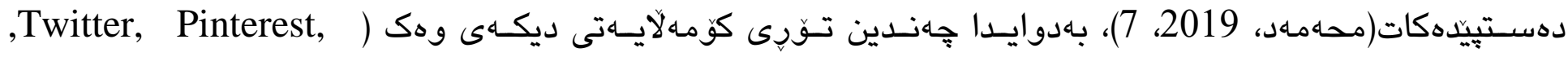

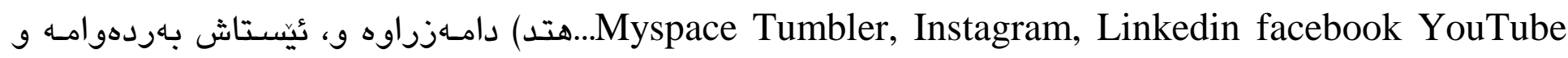

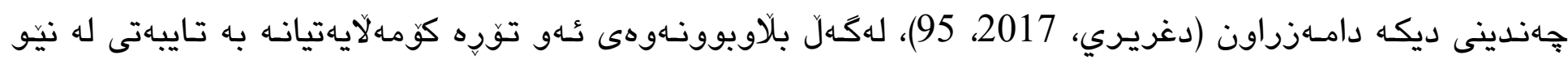

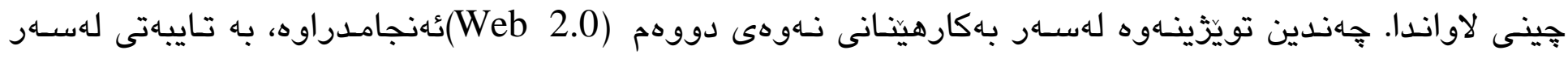

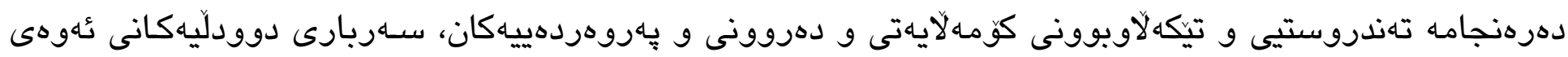

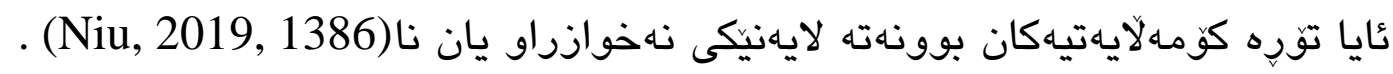

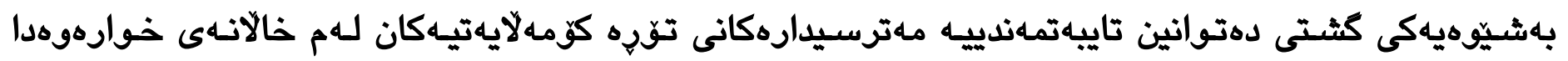
بخهينهروو:

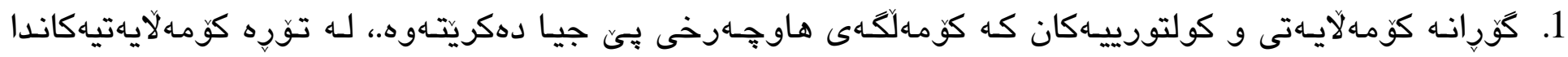

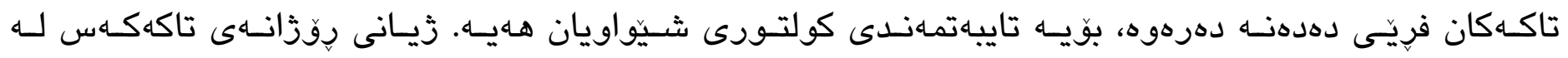

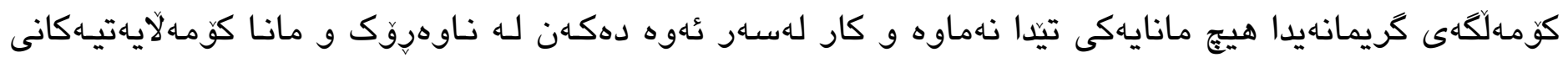
خالّى بكهنهوه (Gordon, 2017, 228). 


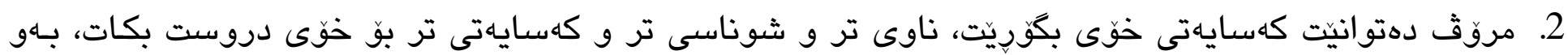

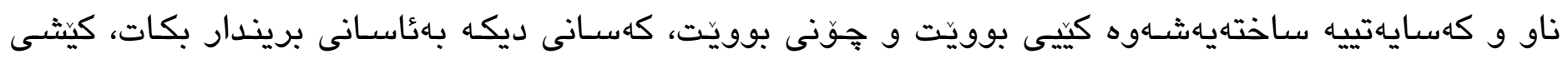
نهاويست بيسريتّهوه (قانع، 2018، 267، 2018).

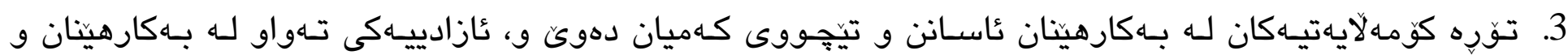

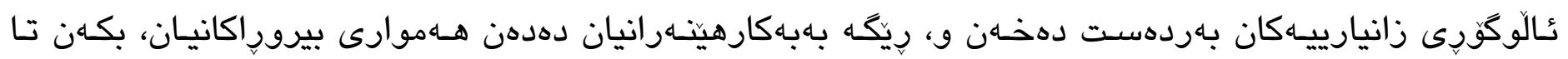
باشتر كوزراشت له بوّجوونهكانيان بكهن (بدوي، 2014، 2017، 217).

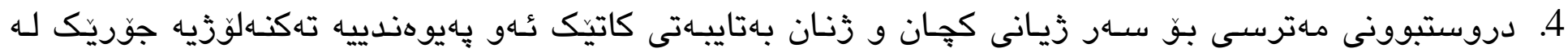

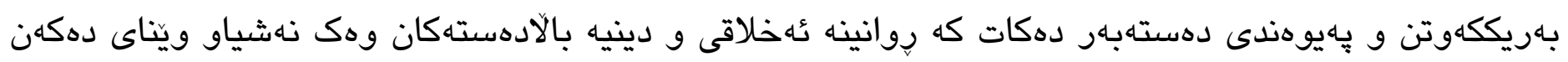

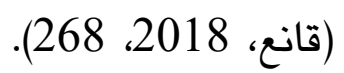

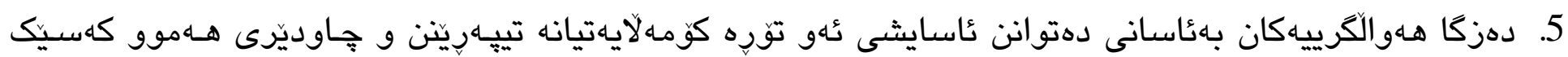
بكهن (محهمهد، 2019، 20 20.

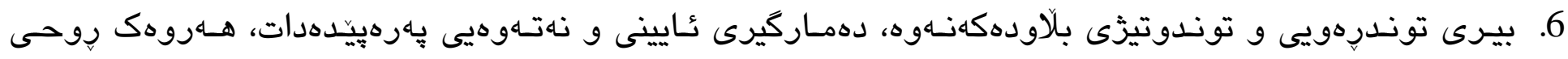

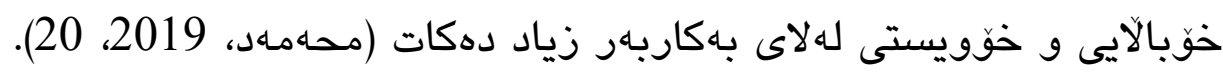

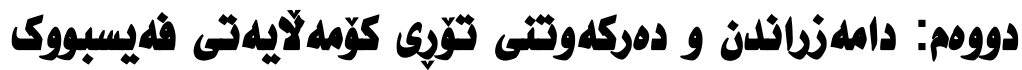

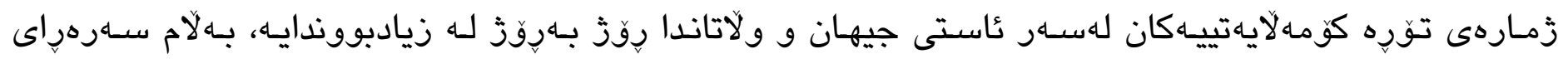

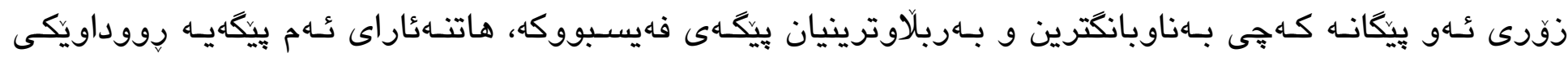

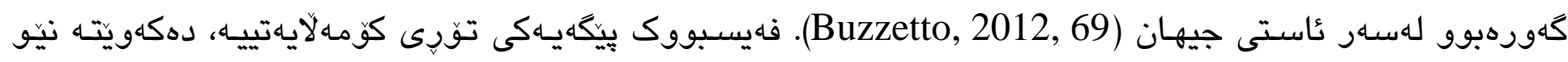

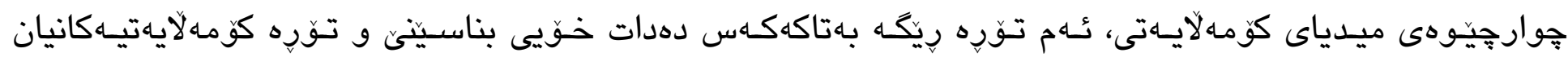

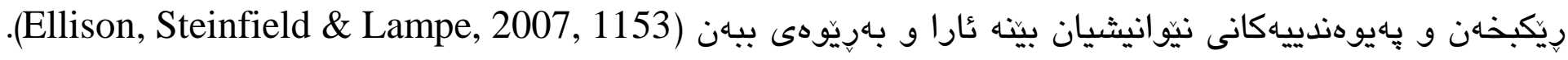

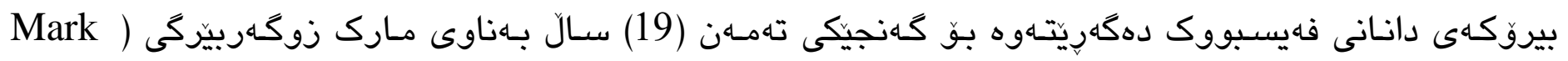

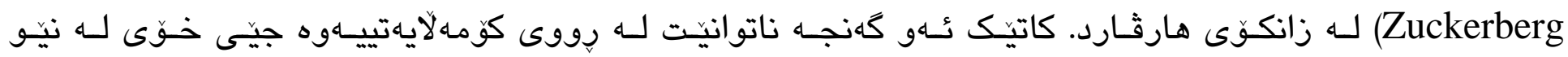

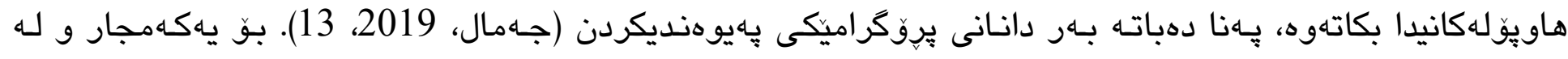

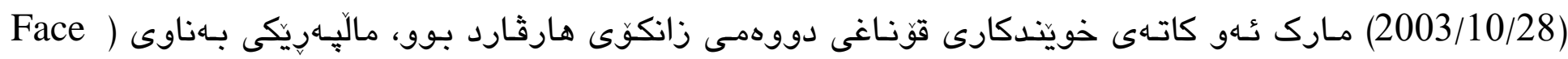

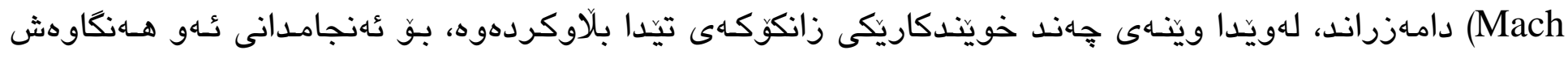

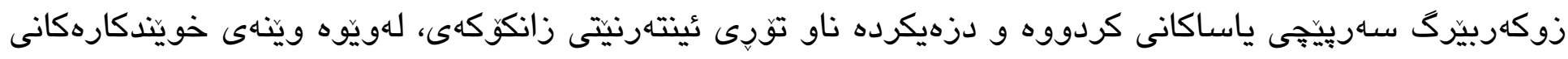

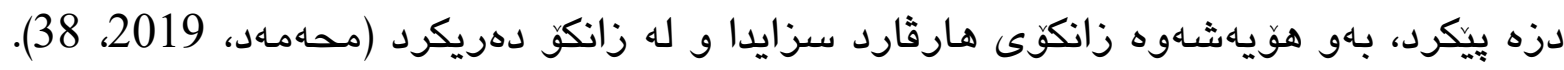
210 


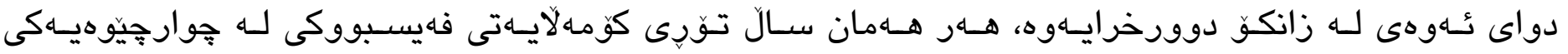

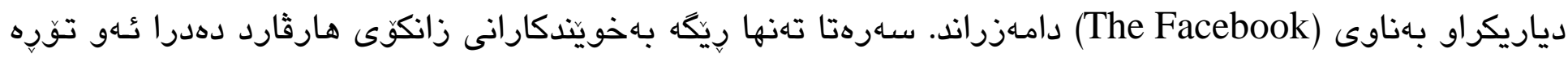

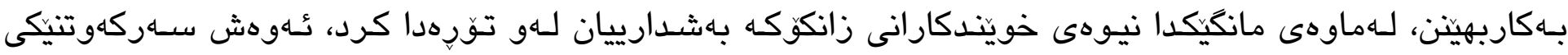

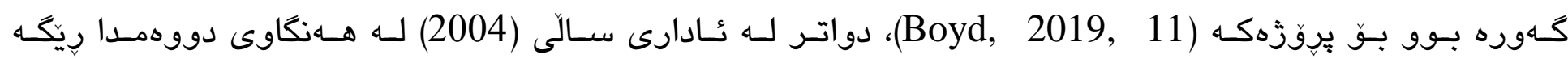

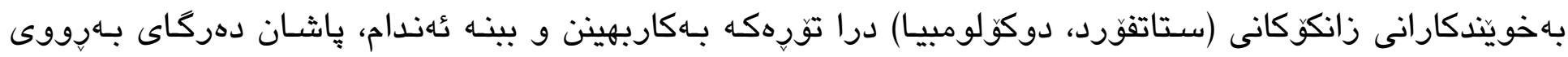

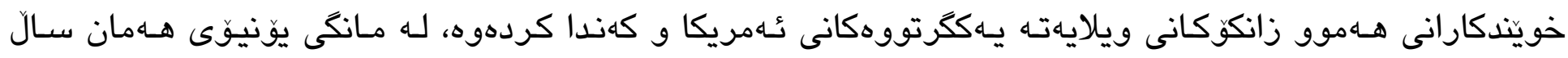

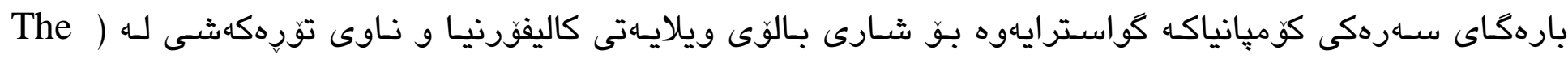

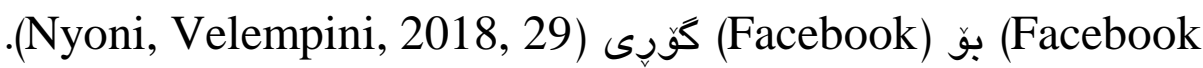

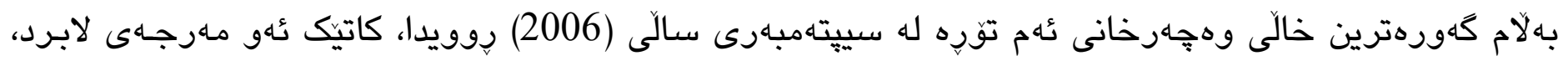

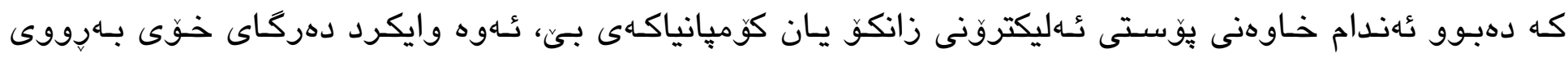

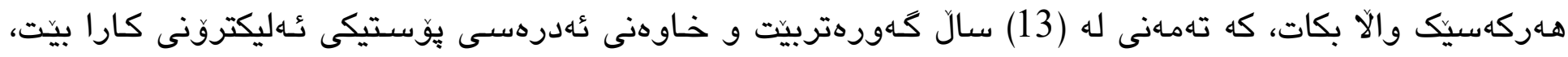

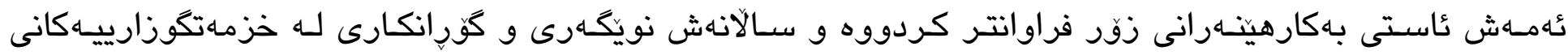

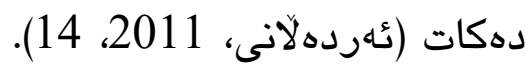

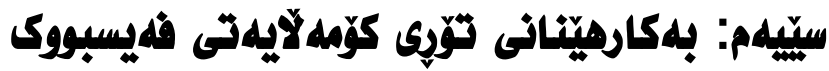

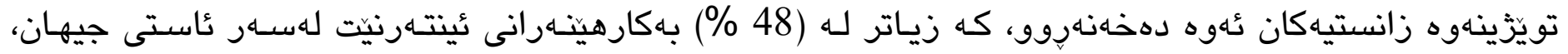

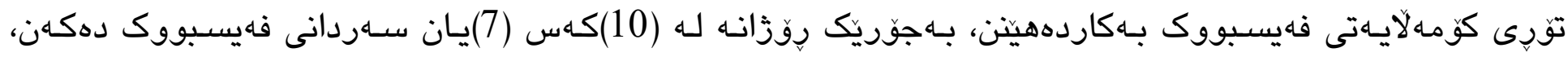

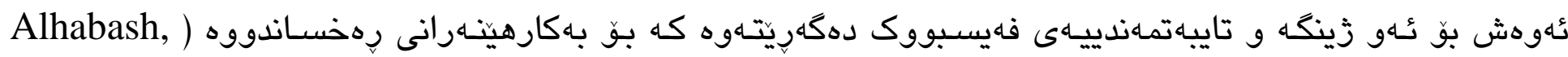

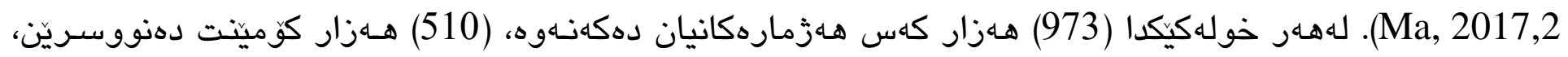

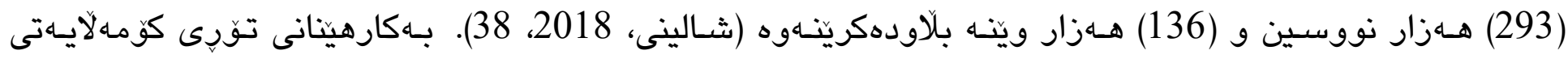

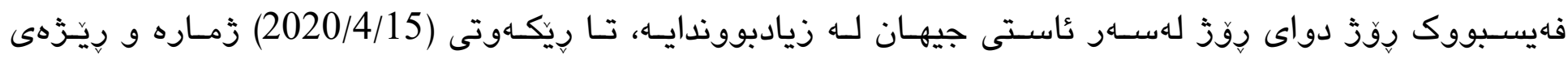

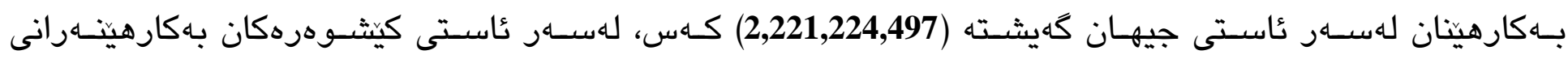
فهيسبووك وهك له شيّوهى (1) خراوهتهروو جياوازه. (internetworldstats, 2020). 
شيّوهى (1) بهكارهينّانرانى فهيسبووك لهسهر ئاستى جيهان بيشان دهدات

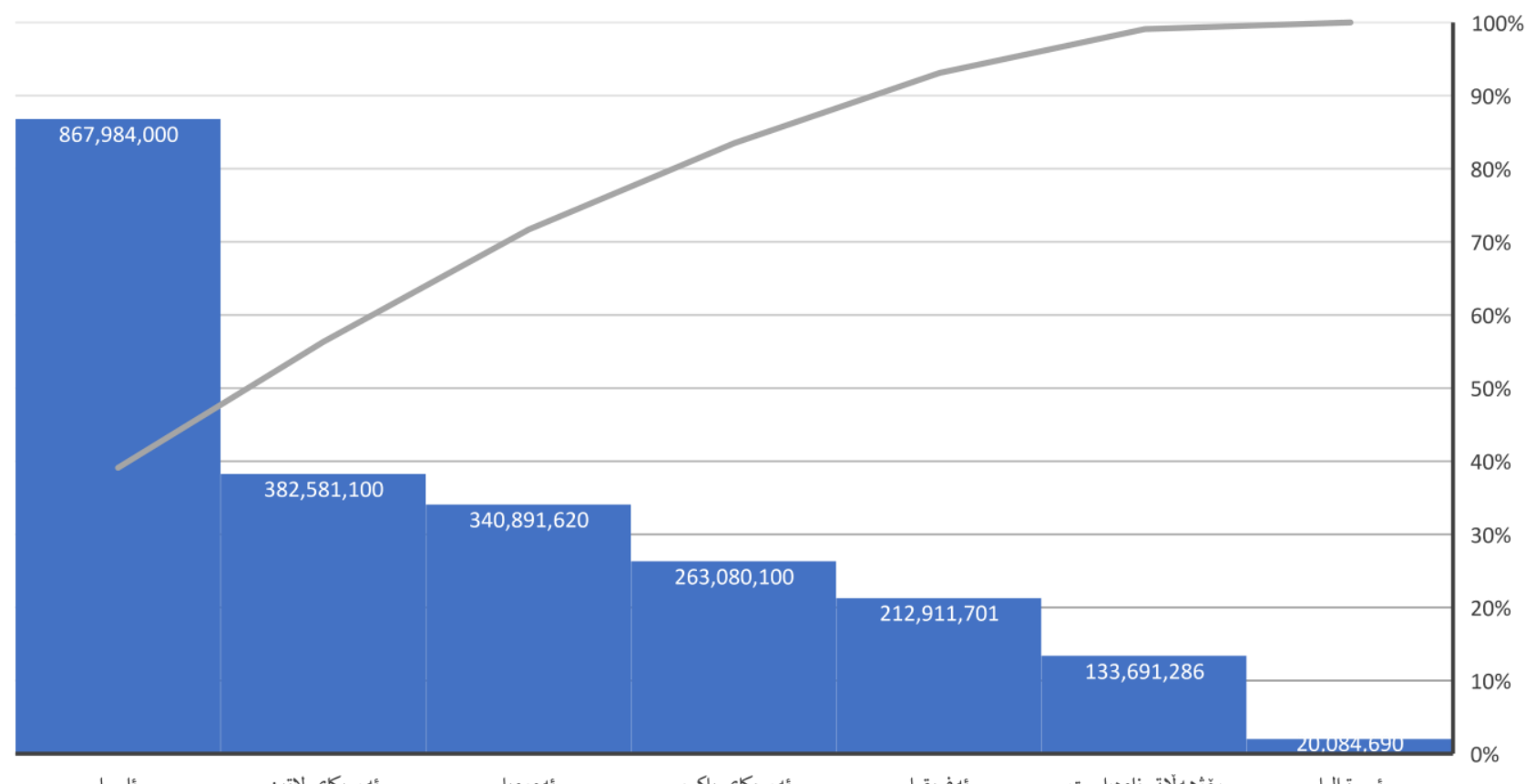

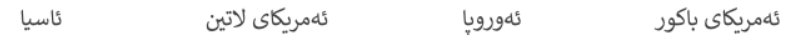

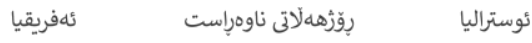

napoleoncat.com \& internetworldstats.com : سهاوهاون

وهك له شيّوهى (1) دهركهوتووه بهريّزهى (39,07 \%) كيشـوهرى ئاسيا لهسهر ئاستى جيهان بهيلهى يهكهم

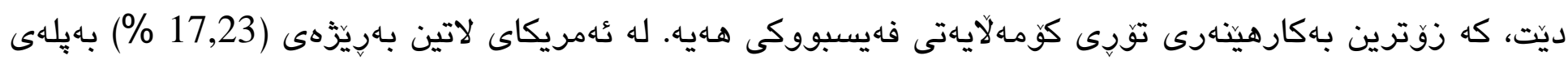

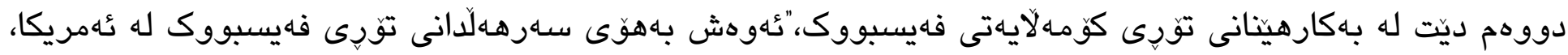

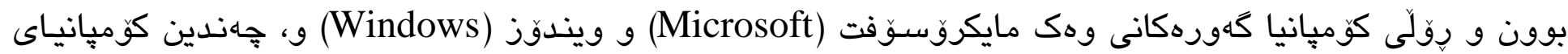

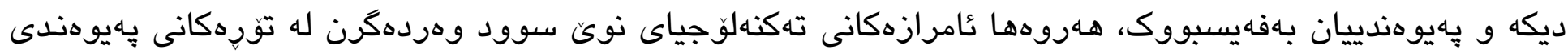

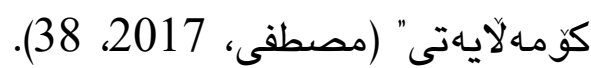

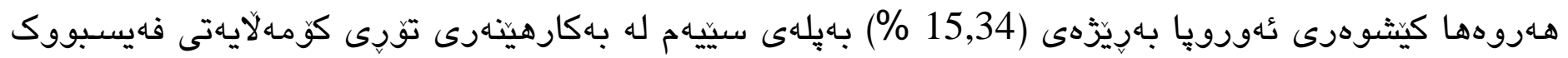

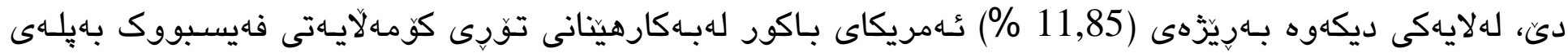

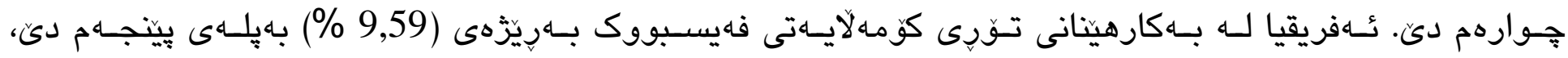

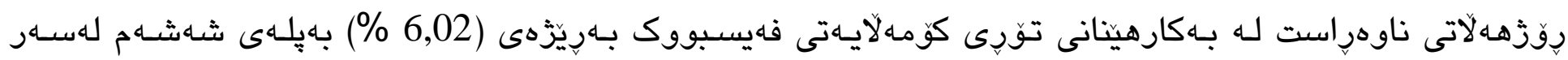

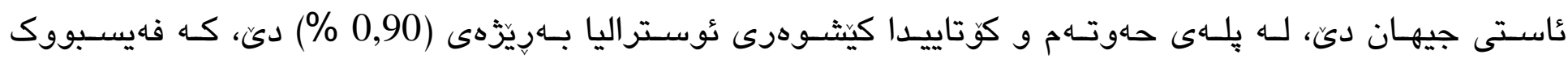
بهاردههينّن. 


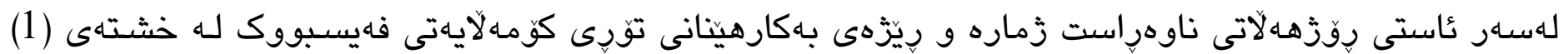
تا ريّكَوتى (2020/4/15) خراوهتهروو (internetworldstats, 2020).

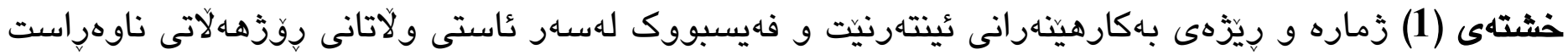
رووندهكاتهوه

\begin{tabular}{|c|c|c|c|c|c|c|}
\hline ي קيّزّه & بهكارهينهرانى فهيسبووك & ي קيّزْه & بهكارهينهارانى ئينتهرنيت & קيّزّه & زمارهى دانيشتوان & ولاتان \\
\hline 1,02 & $1,352,500$ & 0,85 & $1,615,620$ & 0,65 & $1,701,575$ & بهحريّن \\
\hline 29,93 & $40,000,000$ & 35,27 & $67,602,731$ & 32,2 & $83,992,949$ & تئيران \\
\hline 16,45 & $22,030,000$ & 15,56 & $29,820,000$ & 15,34 & $40,026,682$ & عيّراق \\
\hline 4,39 & $5,877,000$ & 3,65 & $7,002,759$ & 3,31 & $8,655,535$ & يُيسرائيل \\
\hline 4,30 & $5,755,000$ & 4,54 & $8,700,000$ & 3,92 & $10,203,134$ & ئوردون \\
\hline 3,06 & $4,093,000$ & 2,3 & $4,231,978$ & 1,63 & $4,270,571$ & كويت \\
\hline 2,98 & $3,967,000$ & 2,89 & $5,546,494$ & 2,62 & $6,825,445$ & لوينان \\
\hline 1,98 & $2,635,400$ & 2,1 & $4,011,004$ & 1,96 & $5,106,626$ & عومان \\
\hline 2 & $2,677,000$ & 1,77 & $3,381,787$ & 1,95 & $5,101,414$ & فهلأهستين \\
\hline 2 & $2,686,000$ & 1,47 & $2,830,970$ & 1,13 & $2,870,656$ & قهتهر \\
\hline 17,75 & $23,720,000$ & 16,62 & $31,856,652$ & 13,35 & $34,813,871$ & سعوديه \\
\hline 5,69 & $7,609,286$ & 3,97 & $7,609,286$ & 6,72 & $17,500,658$ & سوريا \\
\hline 6,55 & $8,737,000$ & 4,97 & $9,532,016$ & 3,79 & $9,890,402$ & ت تيمارات \\
\hline 1,9 & $2,552,100$ & 4,13 & $7,903,772$ & 11,43 & $29,825,964$ & يكامن \\
\hline$\% 100$ & $133,691,286$ & $\% 100$ & $191,645,069$ & $\% 100$ & $260,785,482$ & كوى كثتى \\
\hline
\end{tabular}

napoleoncat.com \& internetworldstats.com

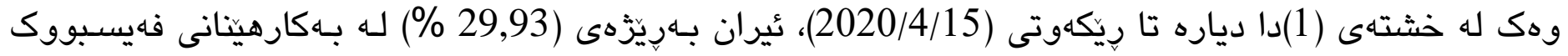

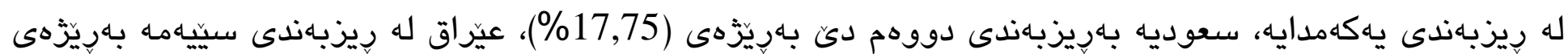

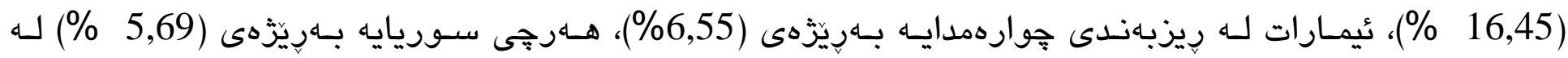

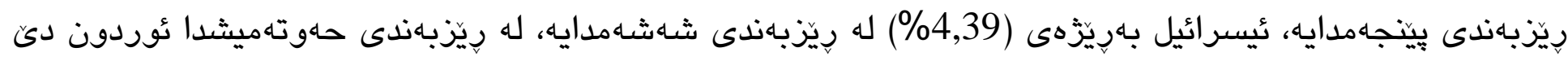

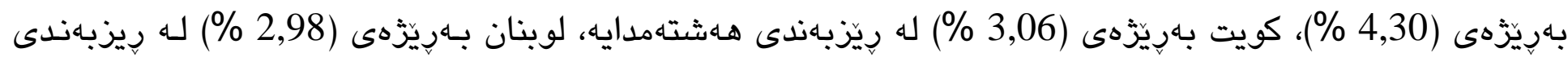

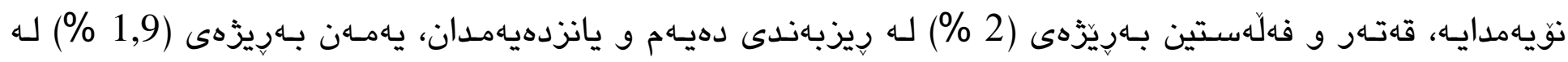




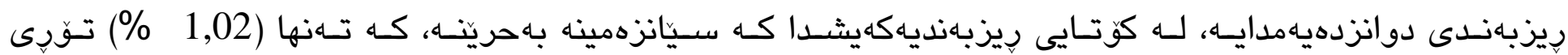

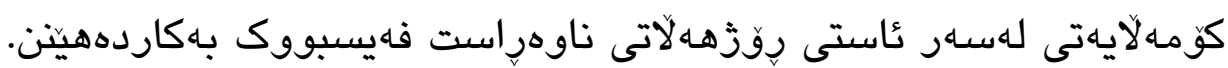

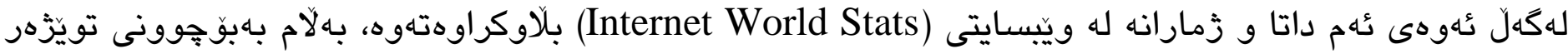

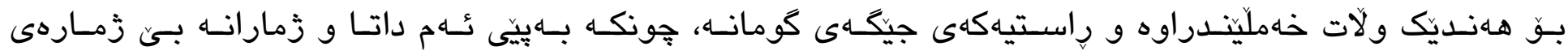

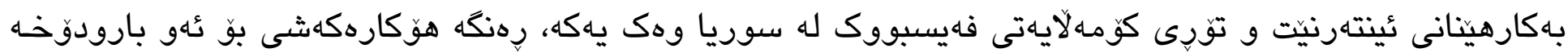

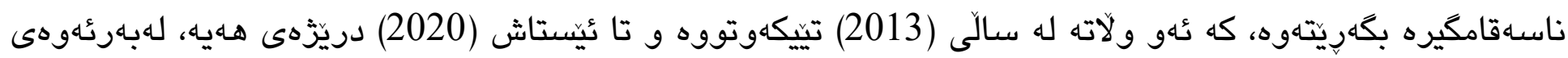

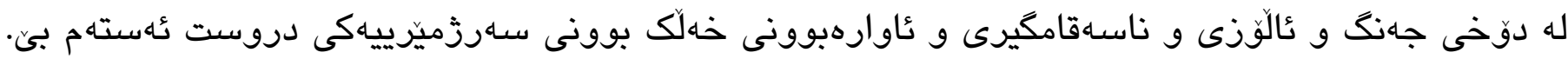

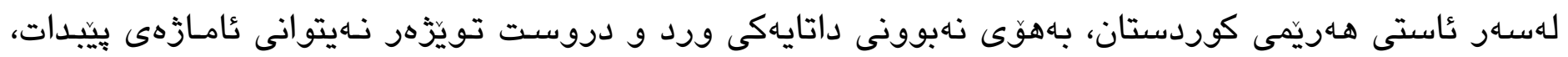

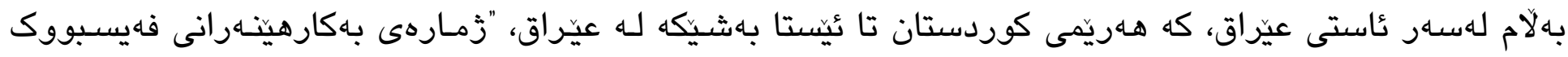

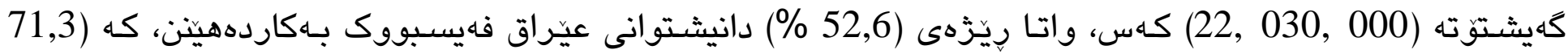

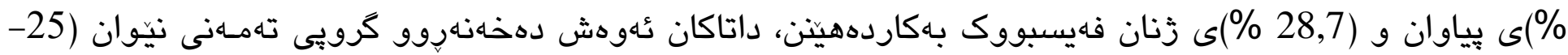

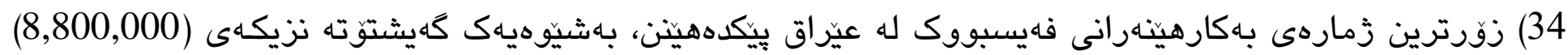
كهس" (NapoleonCat, 2020).

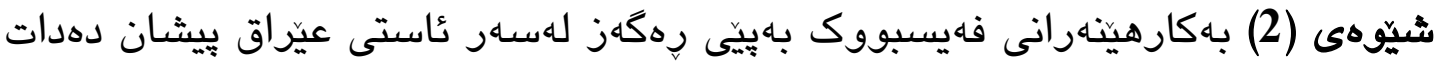

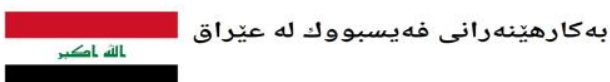

\section{ฉిధి 22030000}

\section{O نئي}

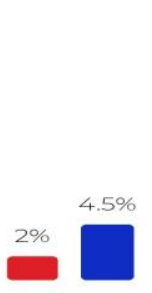

13-17 $6.6 \%$

NapoleonCat.
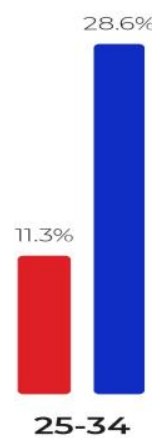

$39.9 \%$

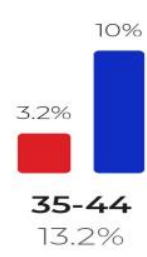

$13.2 \%$

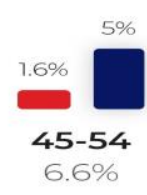

$6.6 \%$

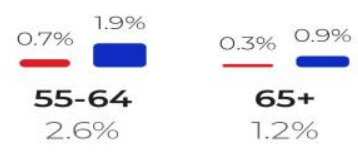

: NapoleonCat.com 


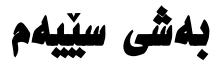

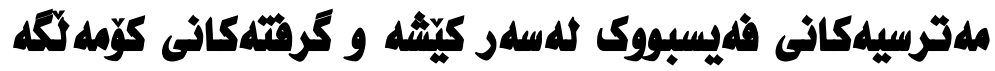

ليّرهدا بهاههند خالِيك باس له مهترسييهكانى توّرى كومهالايهتى فهيسبووك وهك عامرازيكى رِاكهياندن لهسهر ئهو

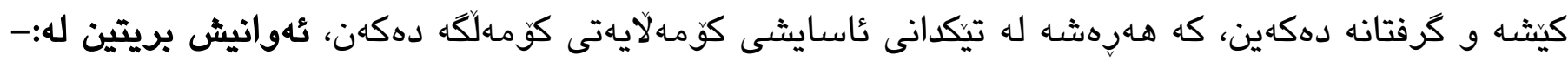

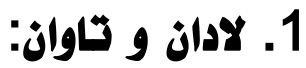

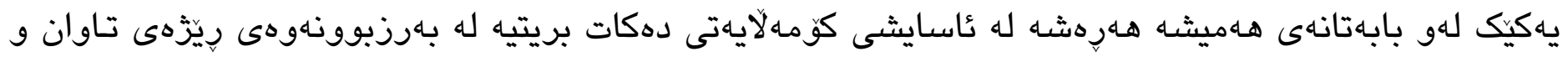

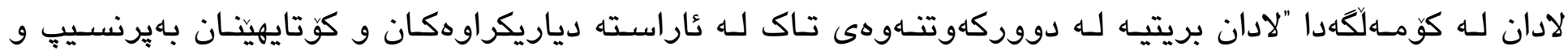

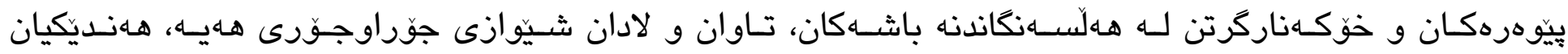

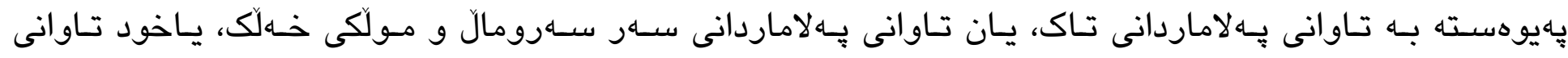

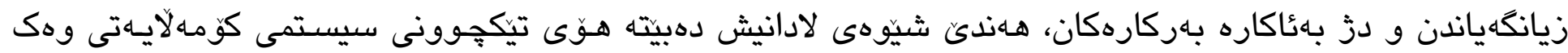
خوكرتن" (يوسف، 2016: 287).

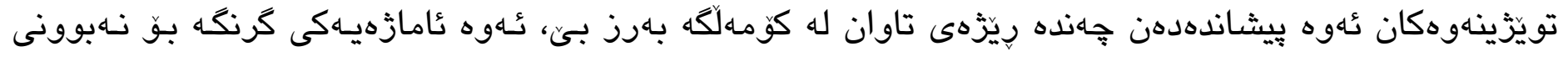

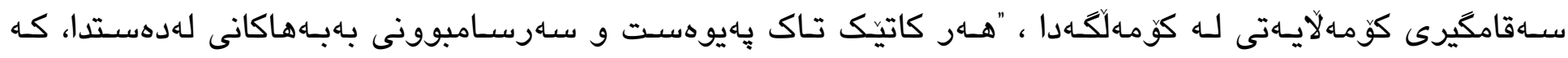

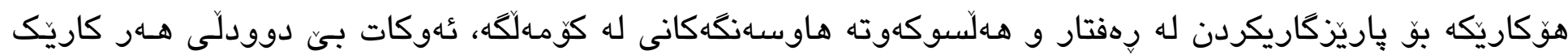

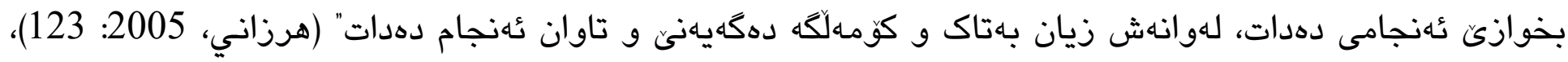

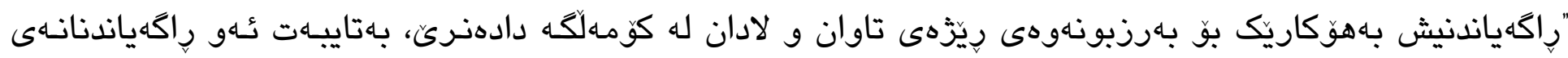

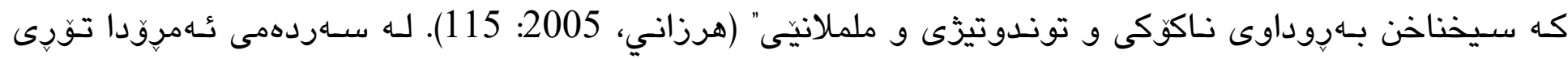

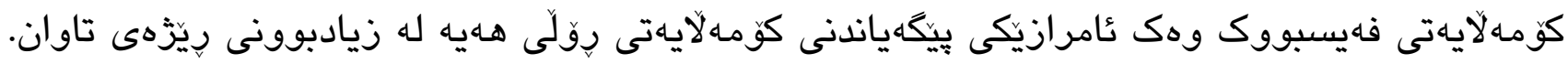

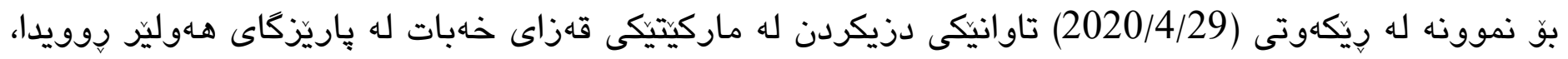

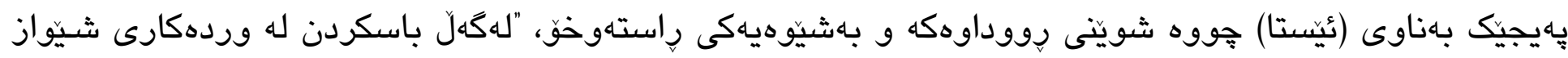

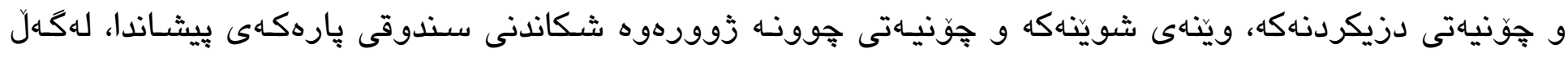

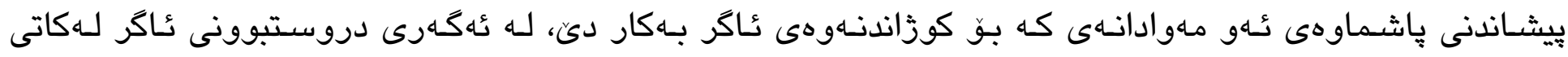
شكاندنى قاسـكاندا".

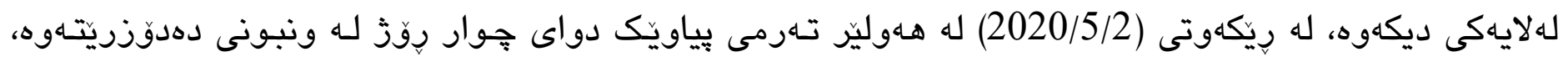

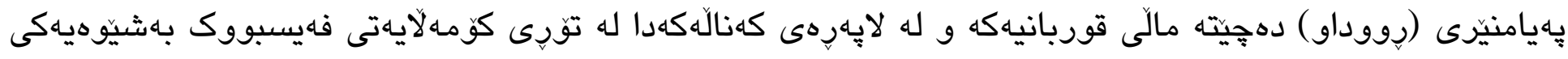

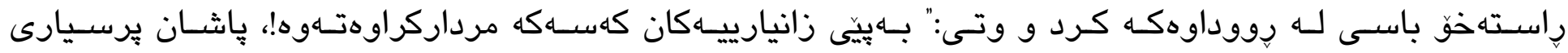


وردهكارى ونبون و شوينتى ونبونى له براى قوربانيهكه دهكات، ئهوش له وهلامدا ئامازه بهشوينتيك دهكات و دهلّي:

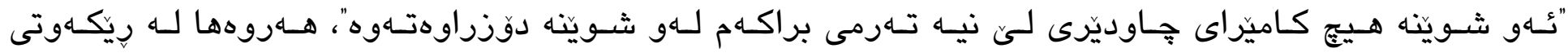

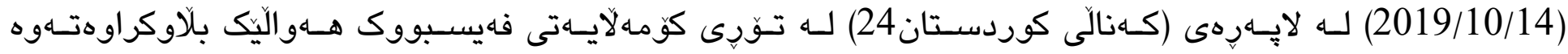

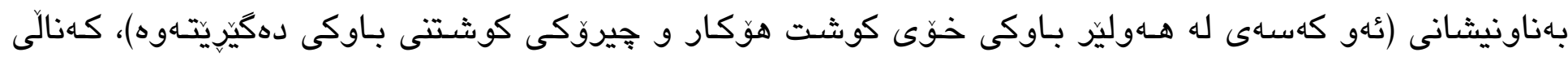

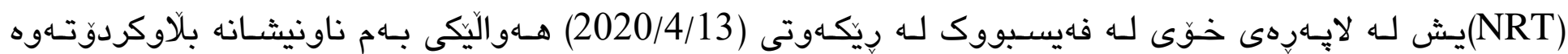

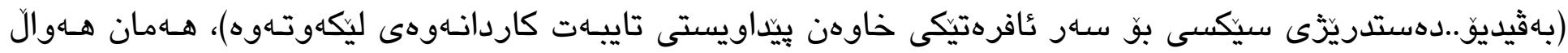

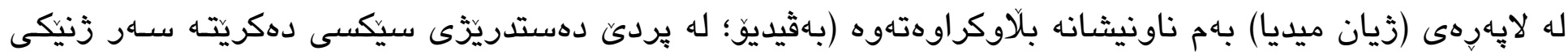

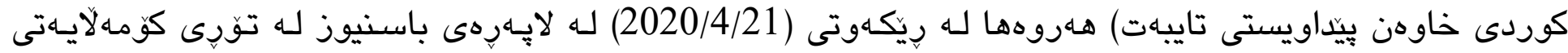

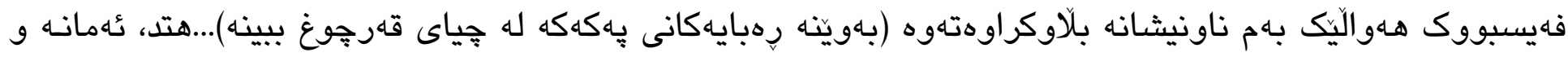

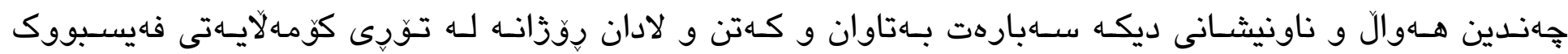
بلاّودهرينَهوه.

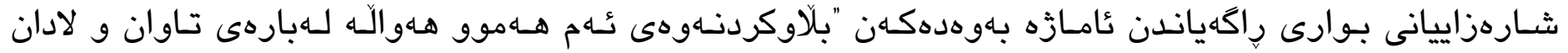

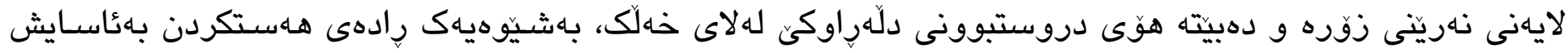

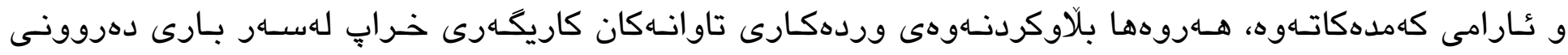

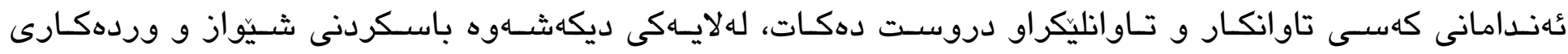
تاوانهكان دهرفهتيك دهدات بهتاوانبار لهكاتى دهستكيركردندا شيّوازى دانيّانانهكهى كَّرانكارى تيّدا بكات، هـهروهها بو ئهو كهسانه شه به بهنيازى ئهنجامدانى تاوانى هاوشيّوهن، سوود له كهموكورييهكان وهردهكرن و تا تاوانهاكانيان

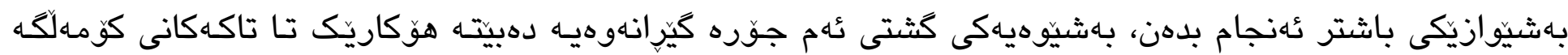

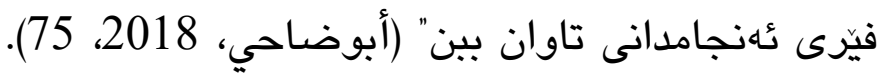

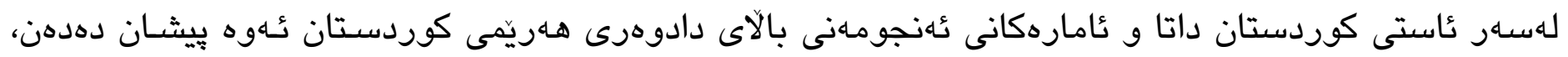

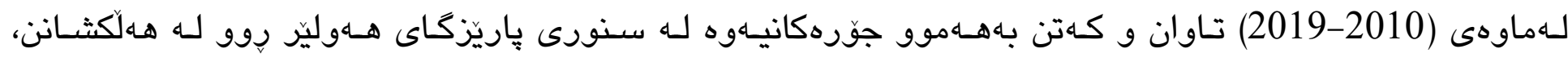

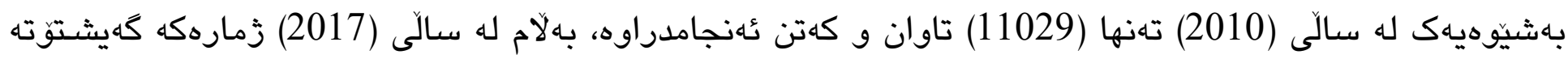

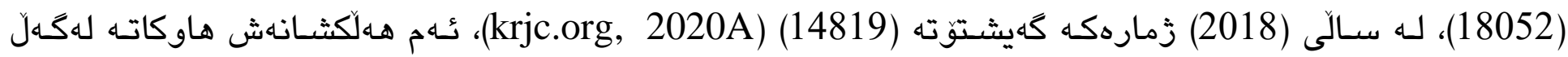

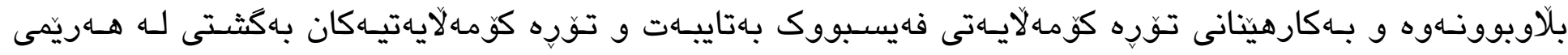
كوردستان، جونكه بههوى نهبوونى ياسايهكى سارددهميانه و نهبوونى شارهزايى و كهمى روّنبيرى بهكارهينان و

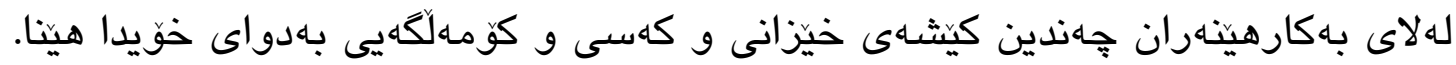

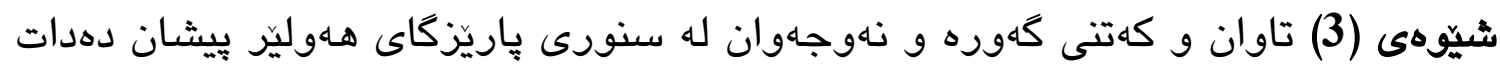




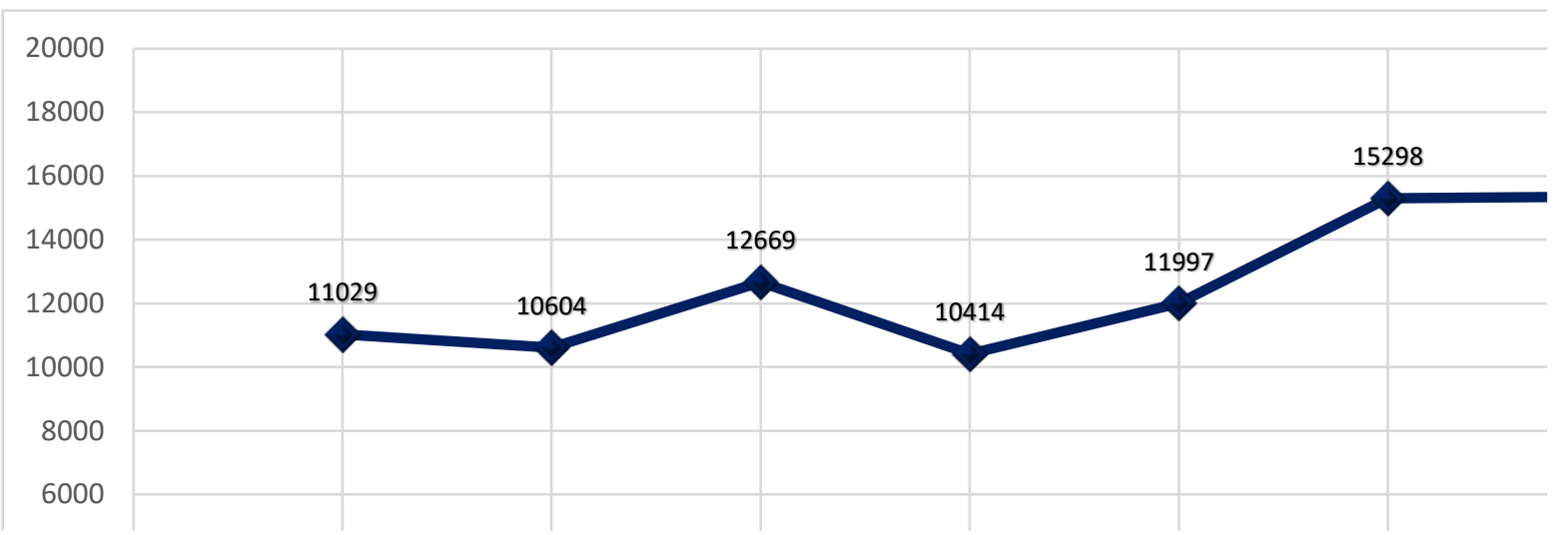

krjc.org سهرجخاوه:

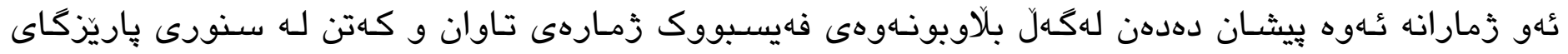

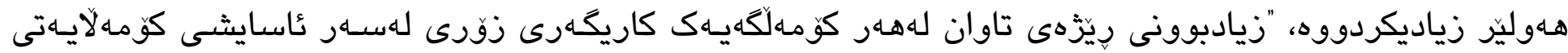

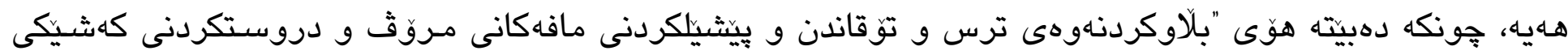

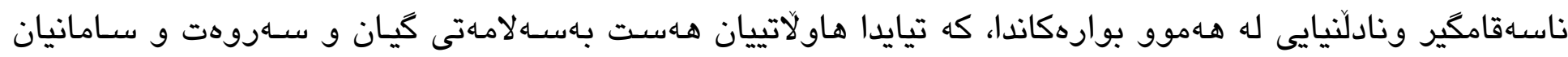

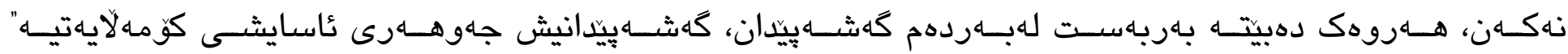

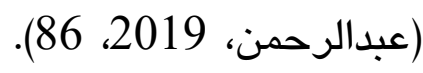

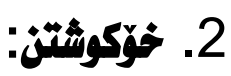

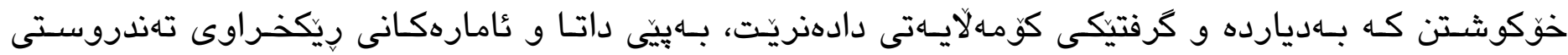

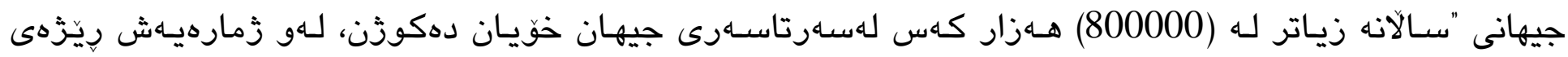

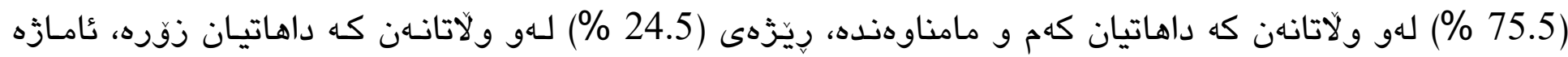

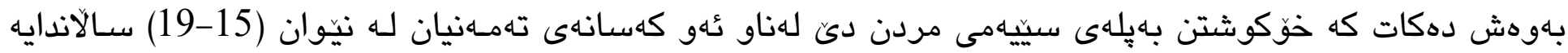
.(Who.int, 2020)

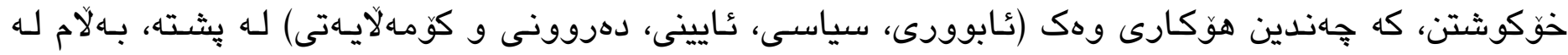

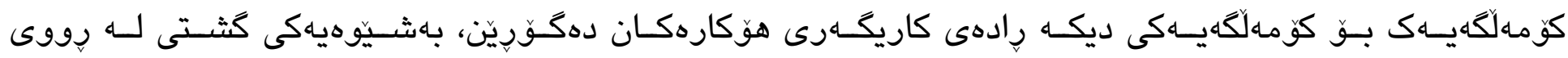

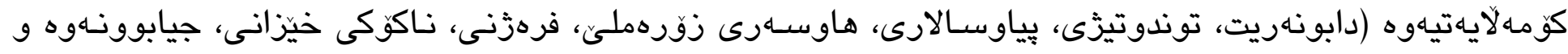

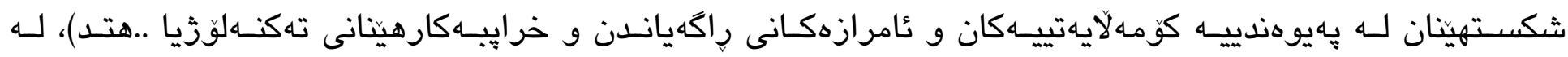
ديارترين هو كارهكانن (فائق، 2019، 263).

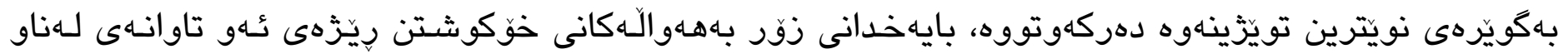

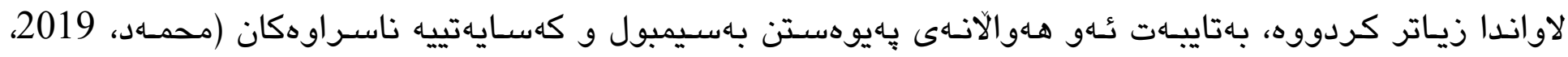




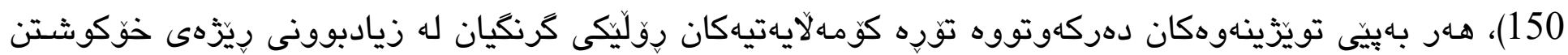

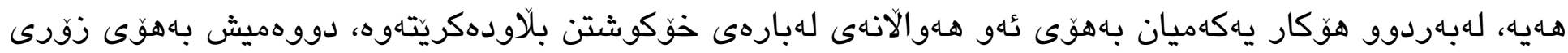

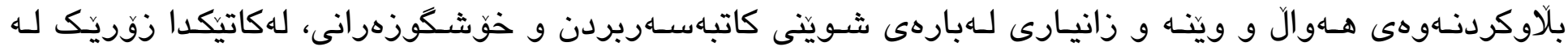

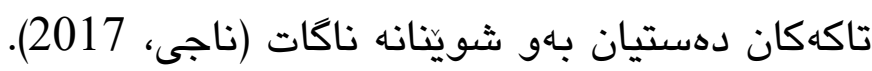

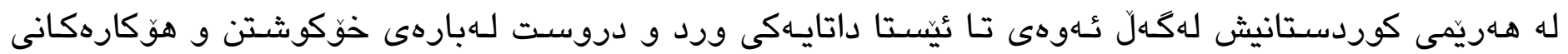

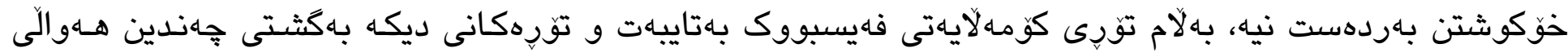

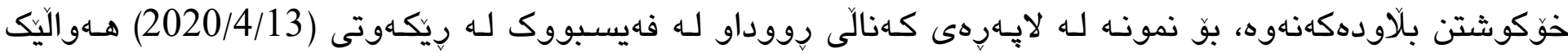

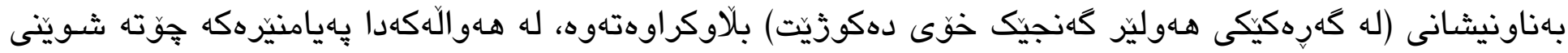

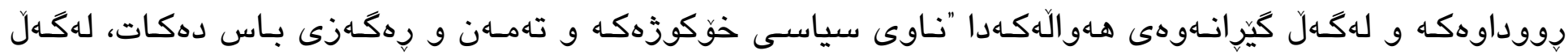

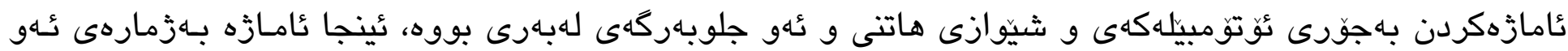

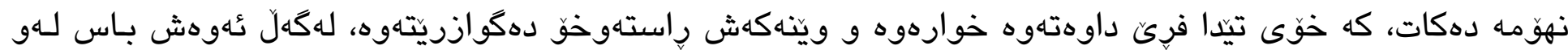

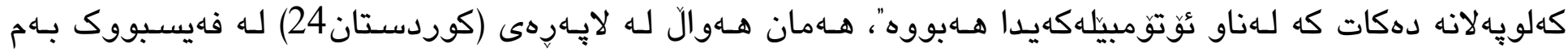

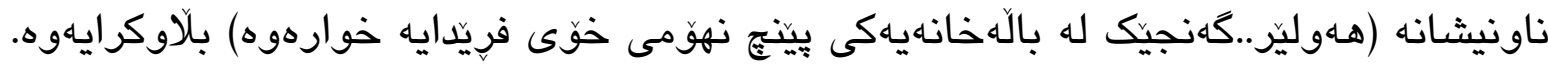

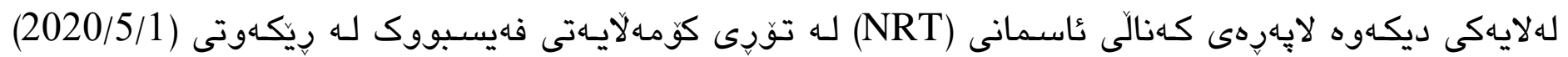

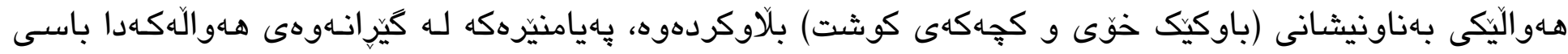

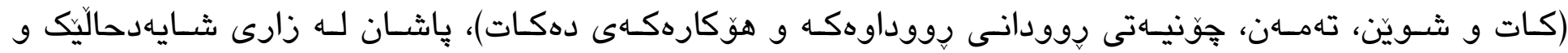

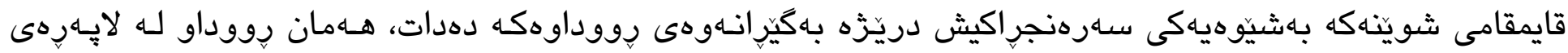

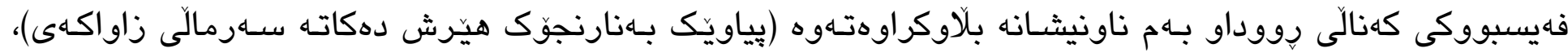

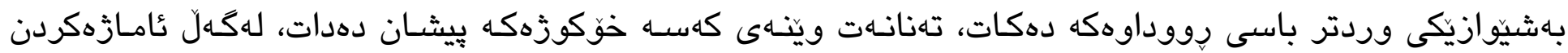

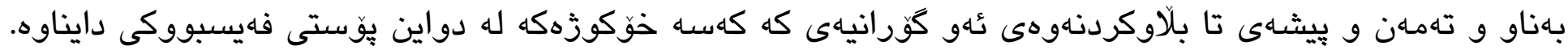

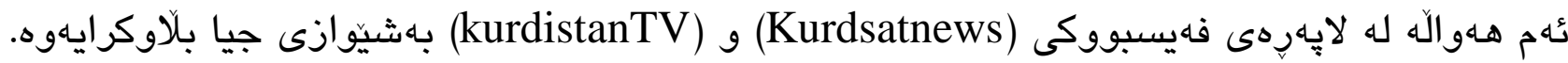

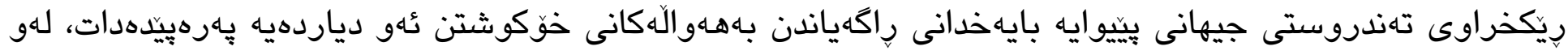

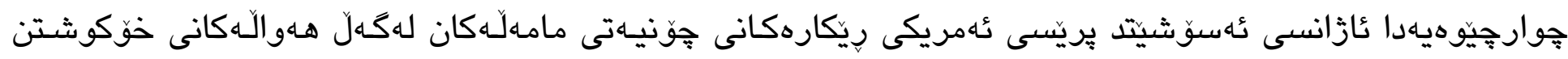

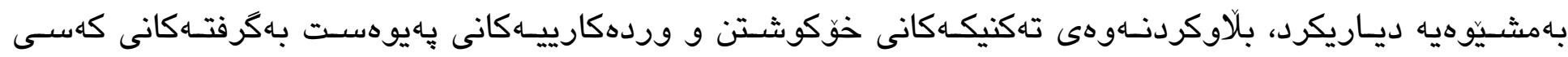

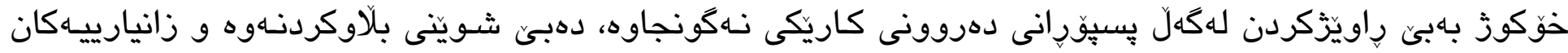

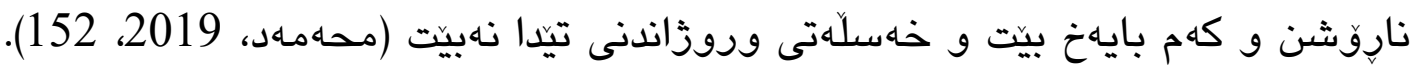




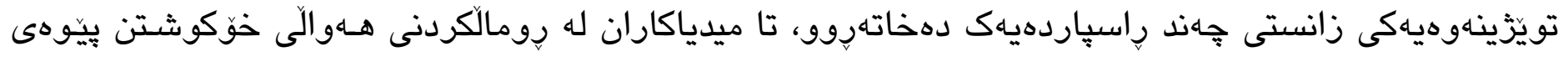

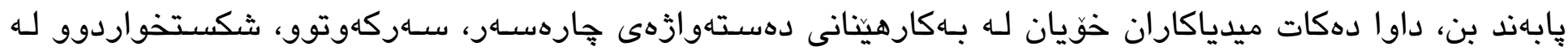

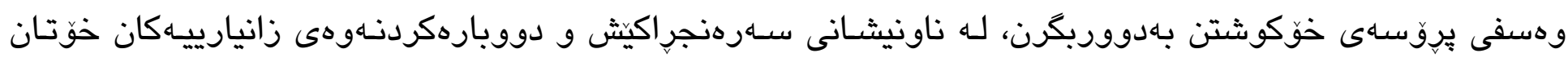

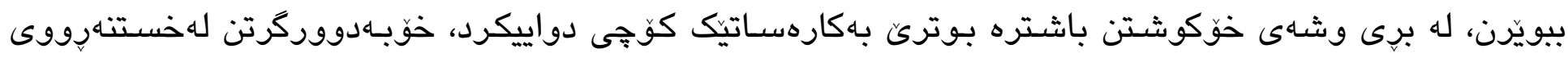

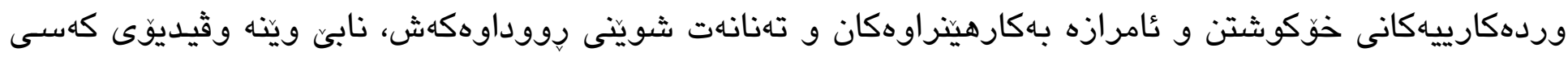

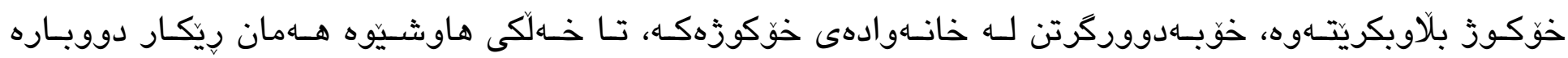

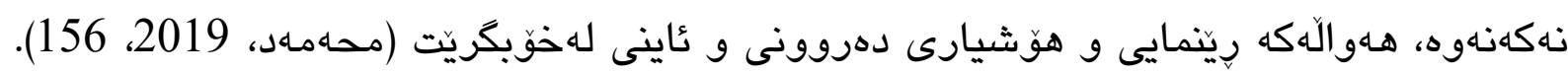

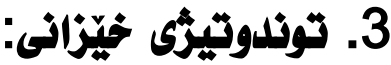

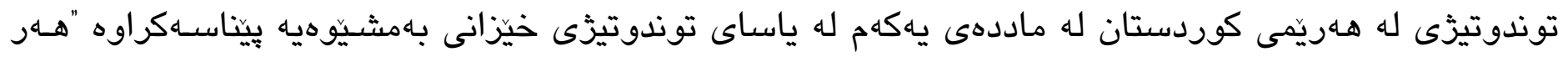

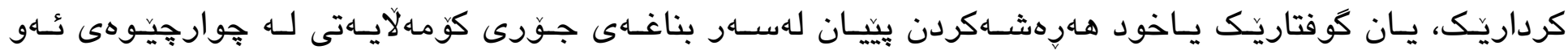

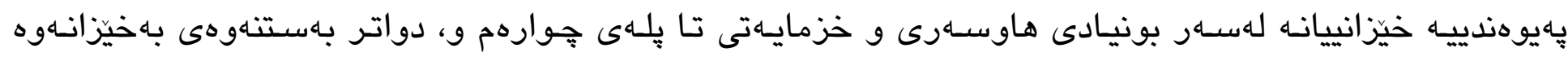

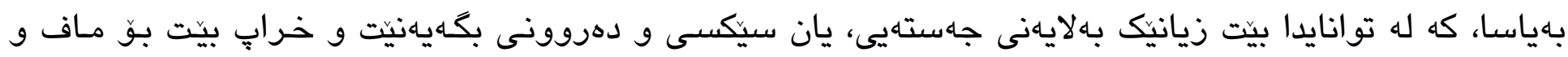

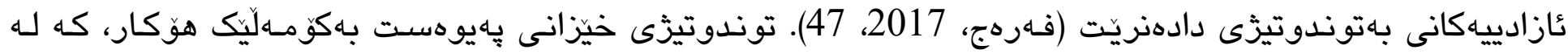

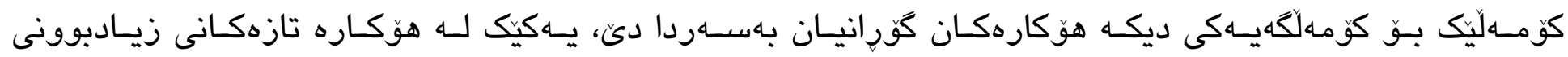

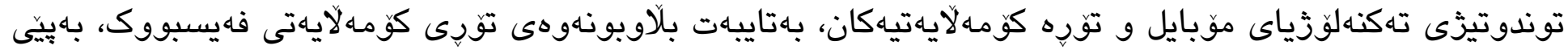

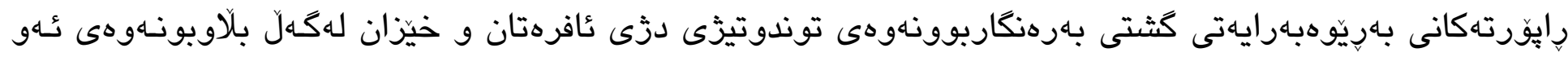

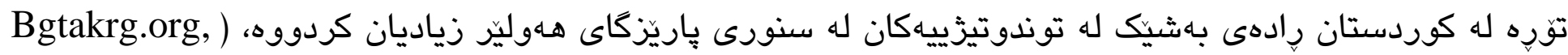

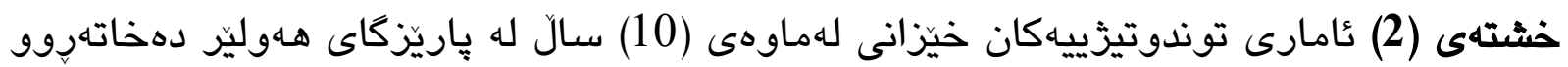

\begin{tabular}{|c|c|c|c|c|c|c|c|c|c|c|c|}
\hline كوى كشتى & 2019 & 2018 & 2017 & 2016 & 2015 & 2014 & 2013 & 2012 & 2011 & 2010 & توندوتيرَييهكان \\
\hline 195 & 16 & 14 & 18 & 9 & 20 & 21 & 28 & 22 & 21 & 26 & كوشتن \\
\hline 173 & 20 & 15 & 28 & 21 & 23 & 19 & 15 & 9 & 11 & 12 & خوكوشتنن \\
\hline 802 & 59 & 47 & 85 & 76 & 68 & 73 & 100 & 114 & 78 & 102 & سووتان \\
\hline 420 & 37 & 33 & 43 & 25 & 52 & 32 & 46 & 45 & 43 & 64 & خوّسووتان \\
\hline 23110 & 4320 & 3419 & 3039 & 2194 & 2796 & 2475 & 1548 & 1213 & 983 & 1123 & سكالاً \\
\hline 219 & 41 & 32 & 34 & 7 & 10 & 12 & 8 & 22 & 18 & 35 & سيكسى \\
\hline
\end{tabular}




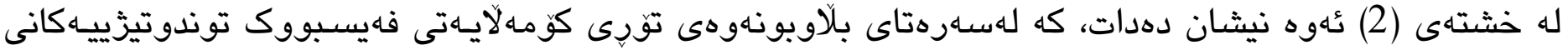
وهك (كوشتن، سووتان) زياديكردوه، بـلاّم له سالآنى دواتر كهميكردوه، جونكه "لهسهرهتاى دهركـوتنى فهيسبووك

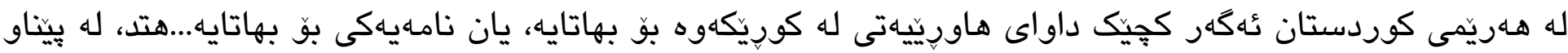

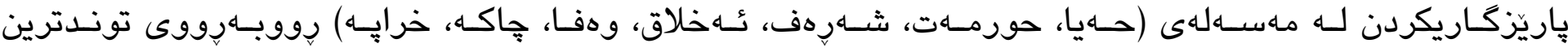
توندوتيزى دهبوهوه تا رادهى كوشتن و سووتان" (رهفيق، 2013، 133)، بـهَّام لـه سـالآنى دواتر خشـتهكه تُهوهان

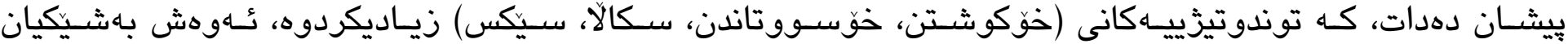

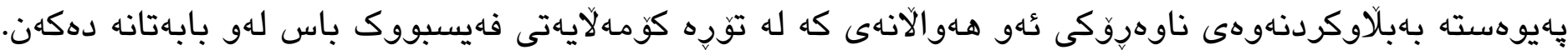

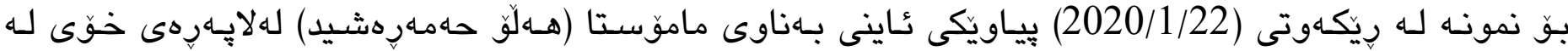

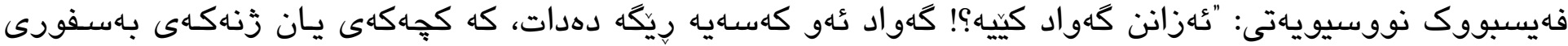

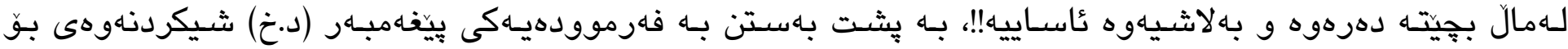

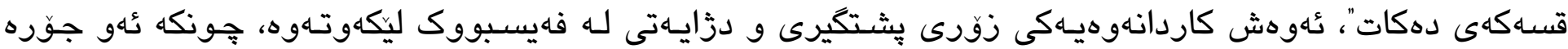

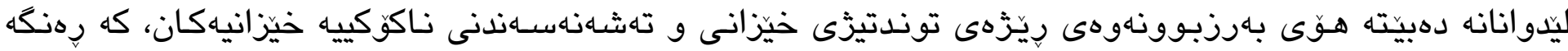

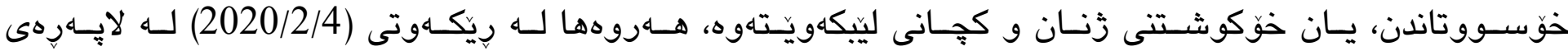

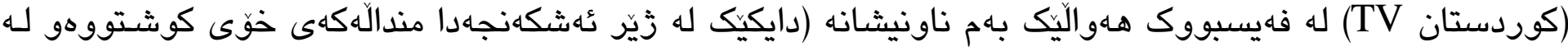

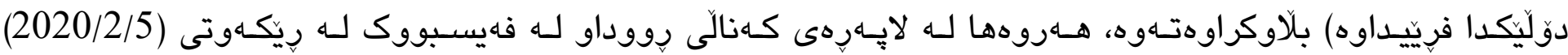

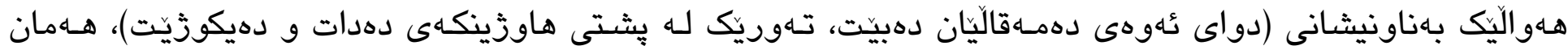
هـوال له (Spee Media) بَّاوكراوهتهوه.

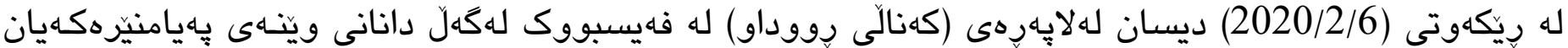

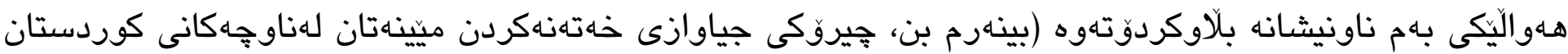

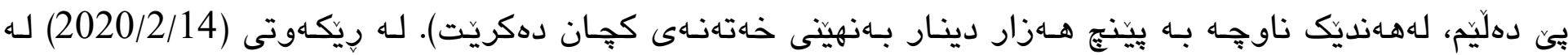

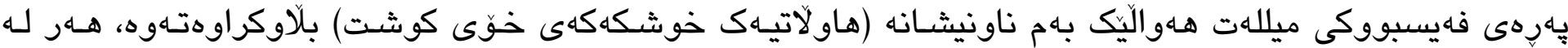

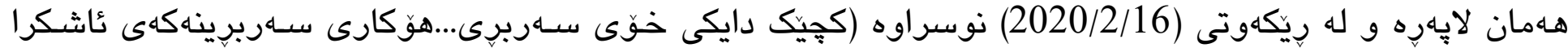

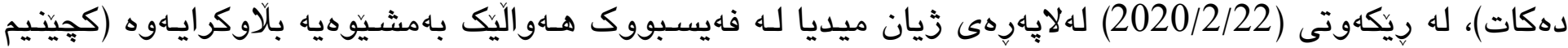

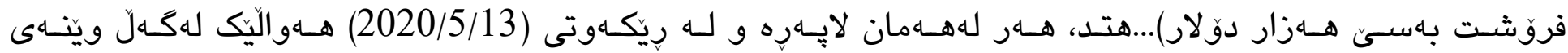

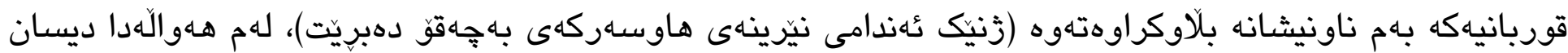
بهوردى باس له هوَكار و جِونيهتى تُهنجامدانى تاوانهكه له زارى زنهكه كراوه! 


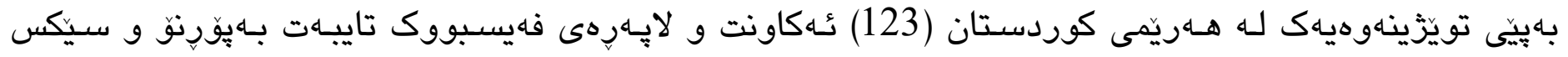

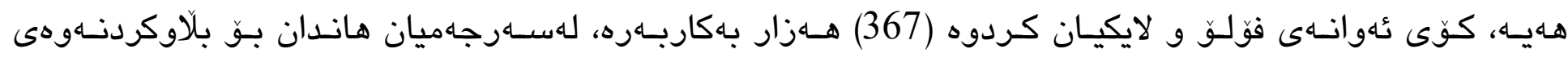

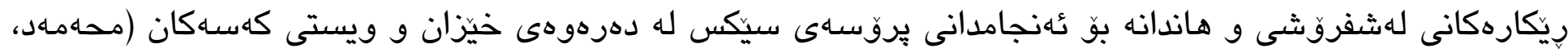

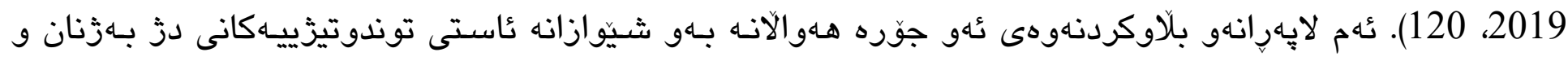
خيزّان بهرزتر كردوتهوه.

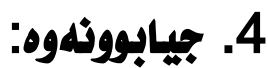

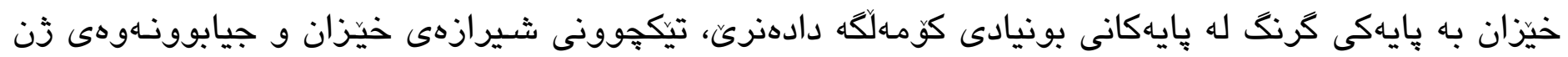

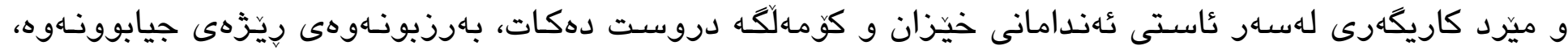

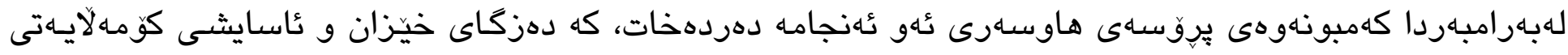

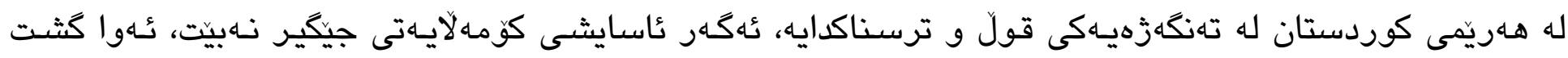

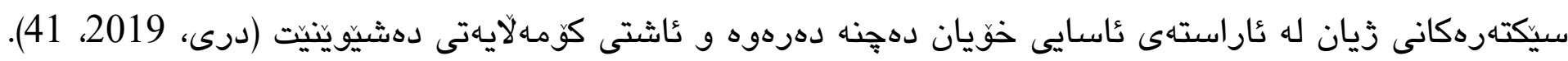

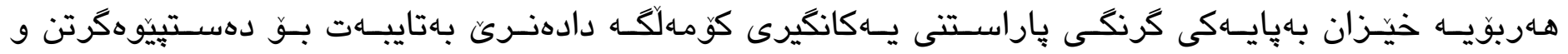

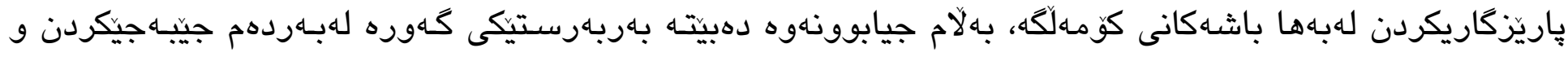

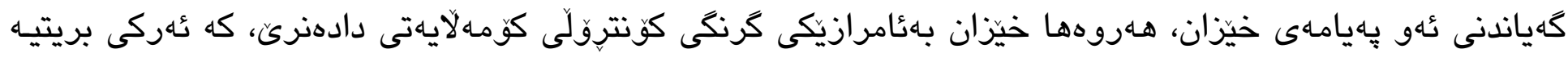

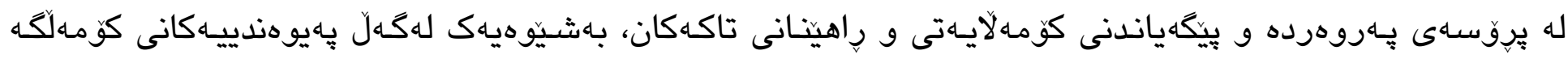
يه كبكريتّهوه (سمير، 2009: 97).

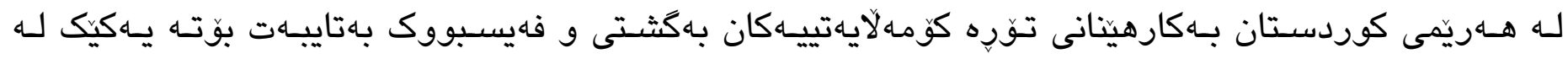

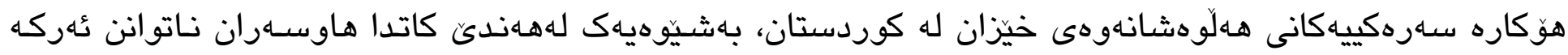

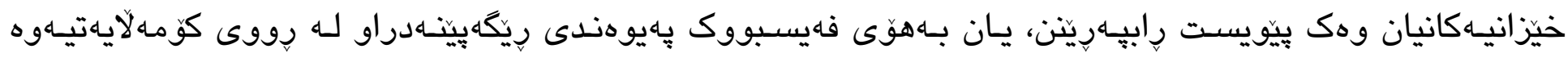
له گَل رهكَزى بـهرامبهر دروست دهكهن و بايهخدانى جارانيان بههاوسـهرهانيان نامينتى، تُهوه جگه لـه باسكردن و

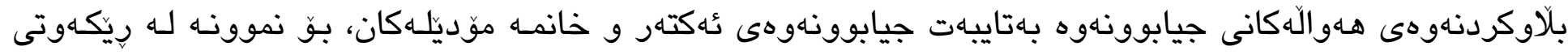

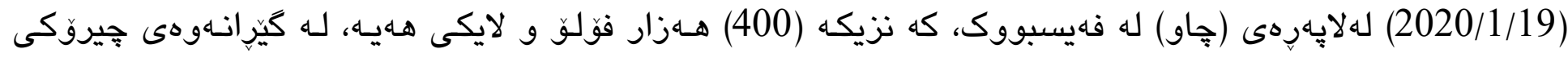

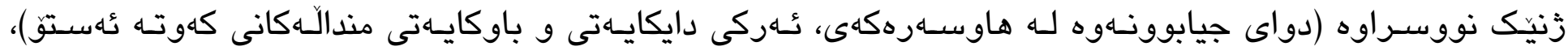

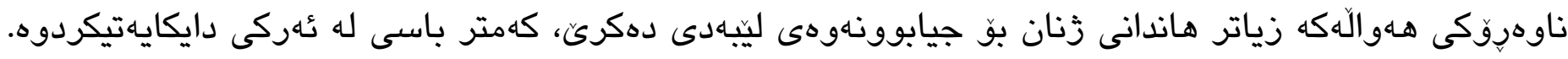

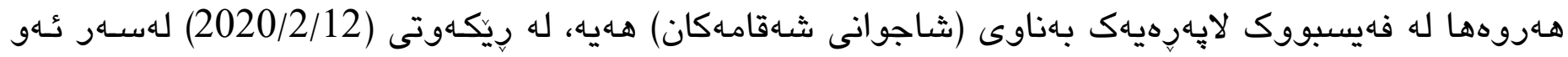

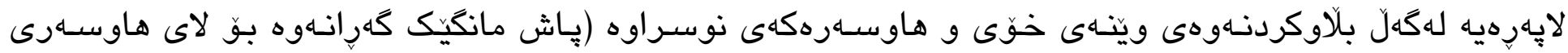




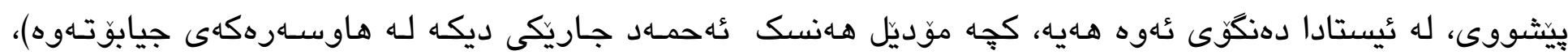

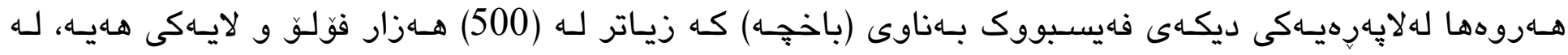

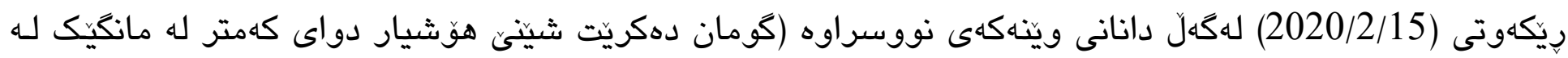

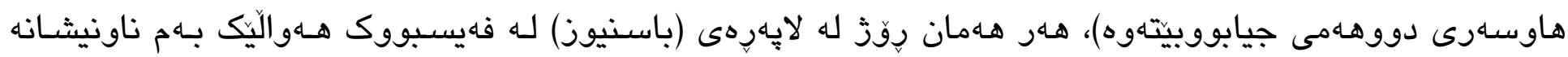

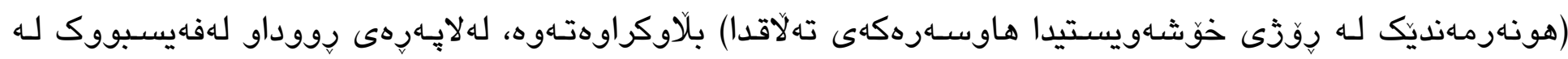

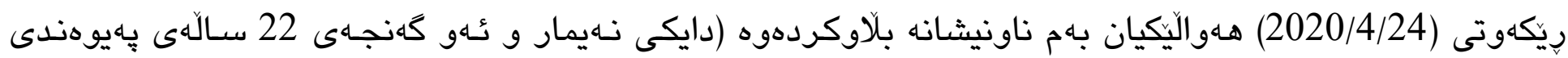

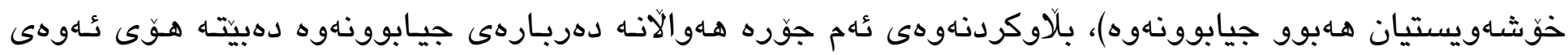

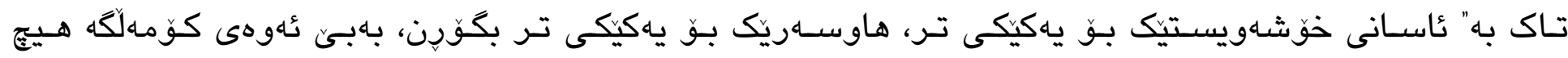

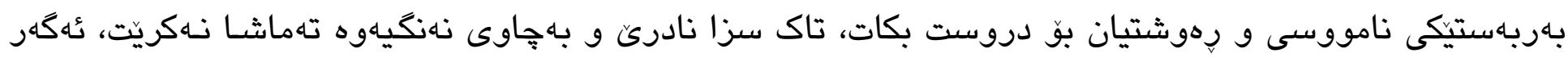

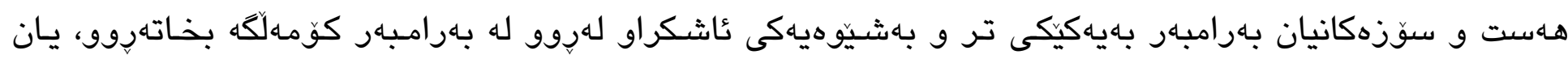
باسى بكا" (خهليل، 2002، 227).

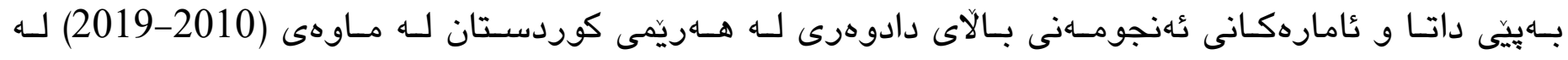

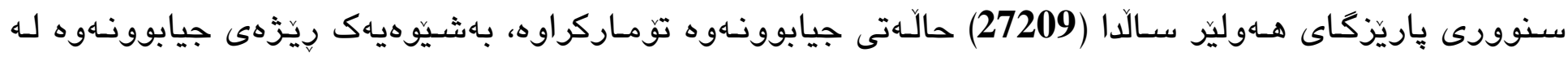

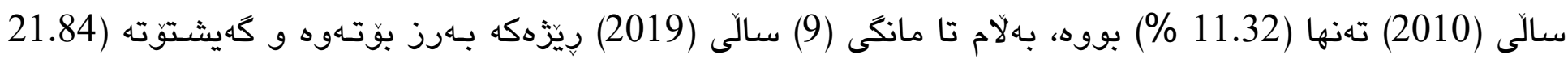
.(krjc.org, 2020B) (\%

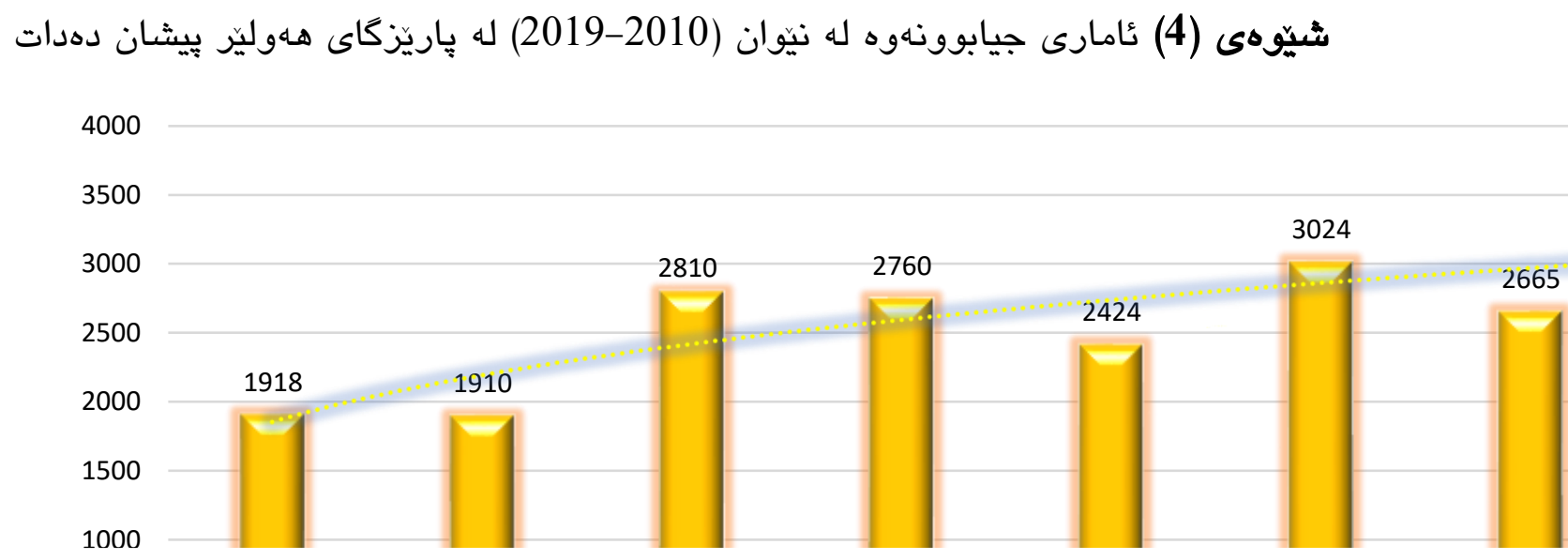

krjc.org سهرجهاوه:

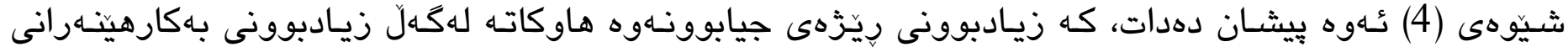

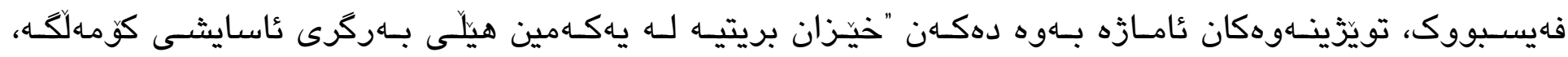

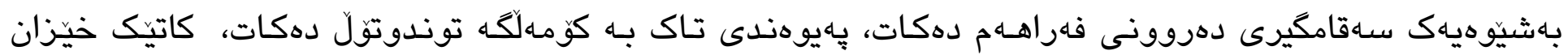




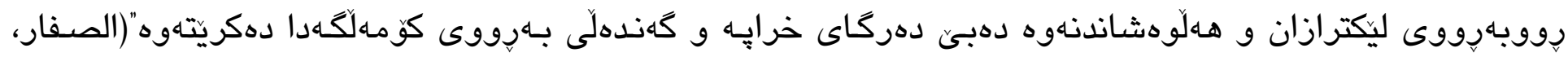

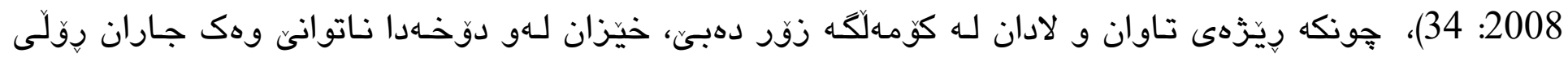

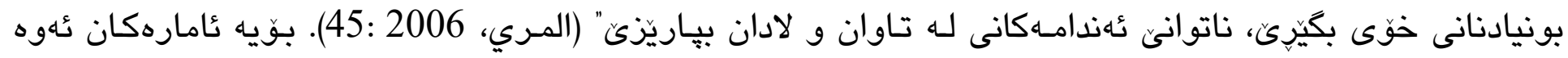

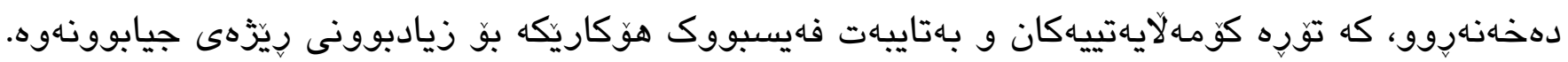

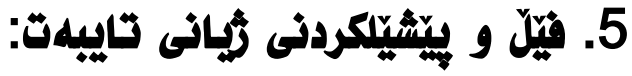

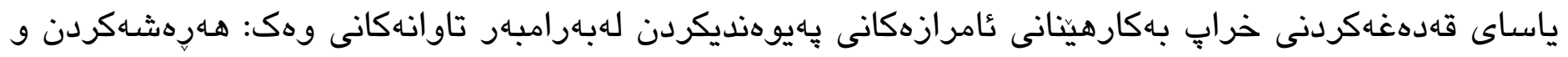

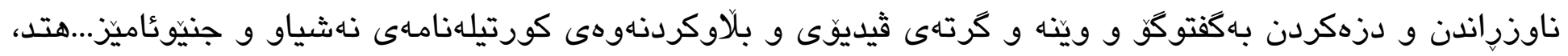

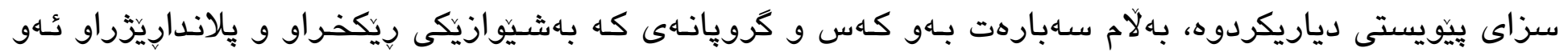

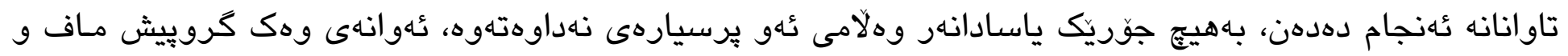

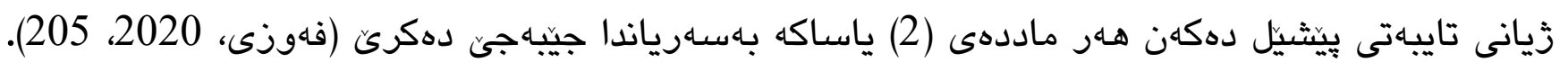

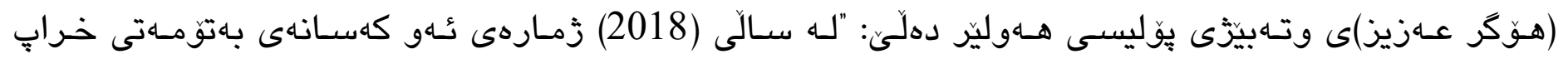

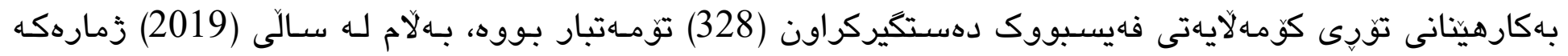

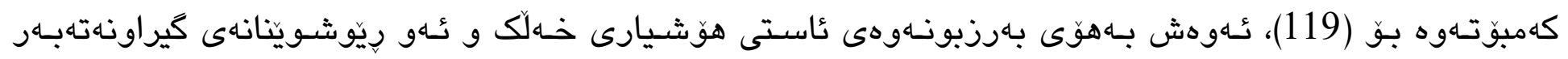

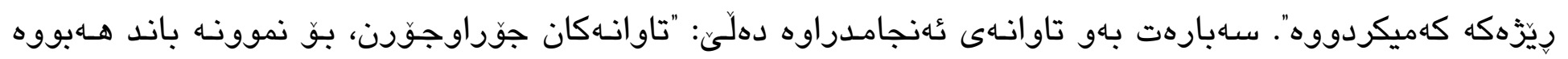

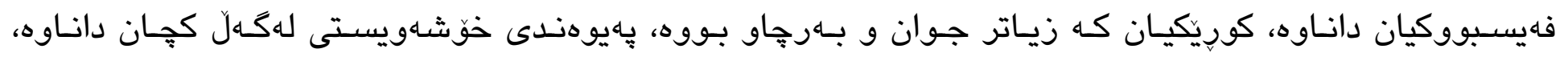

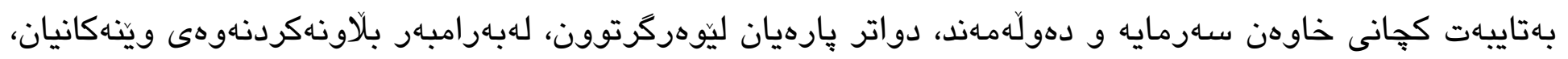

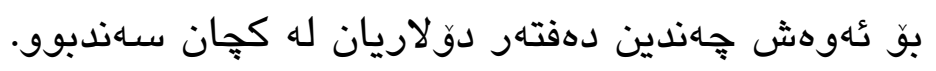

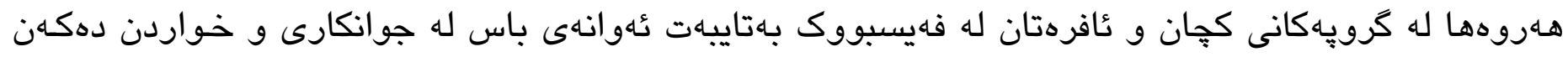

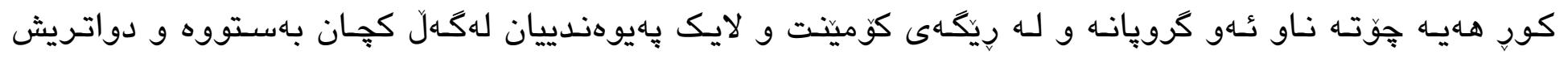

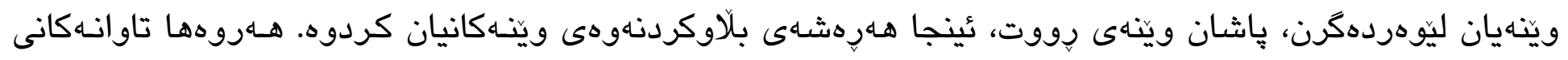

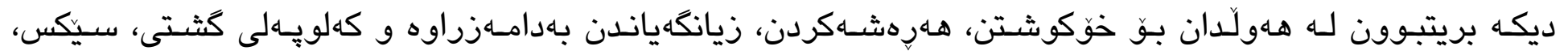

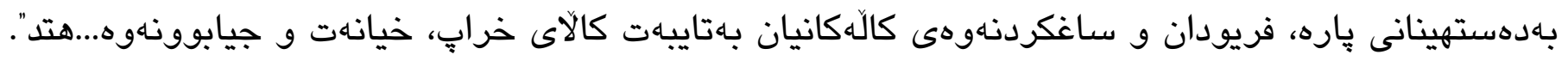

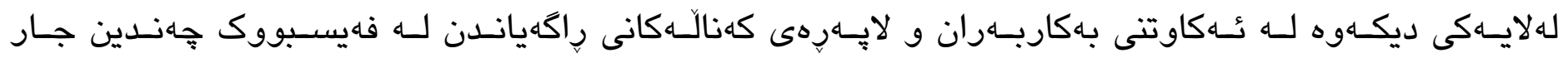

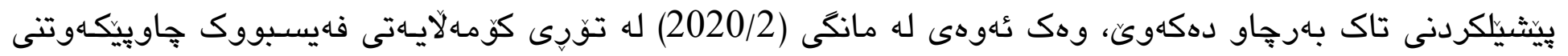

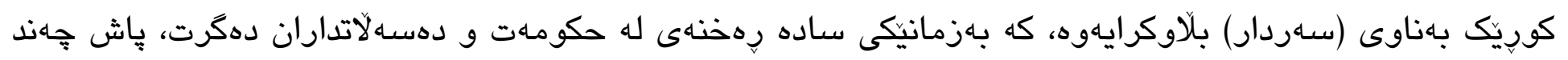

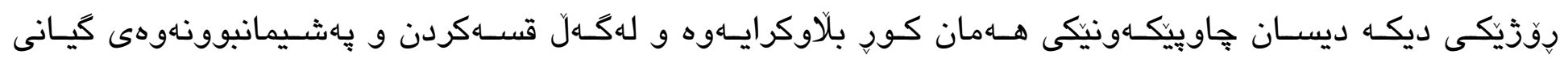

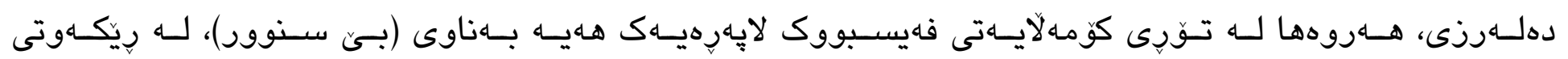
224 


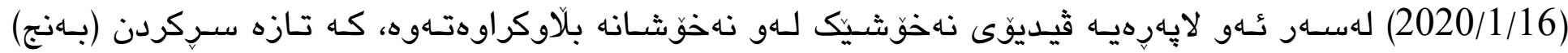

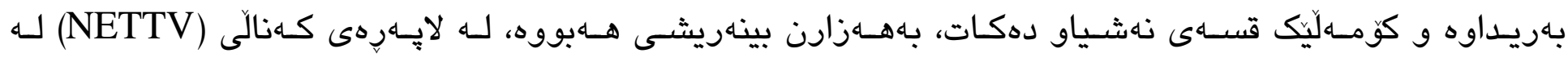

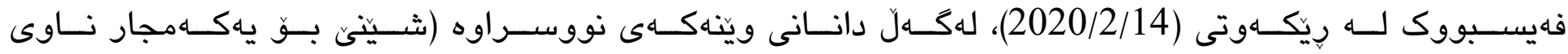

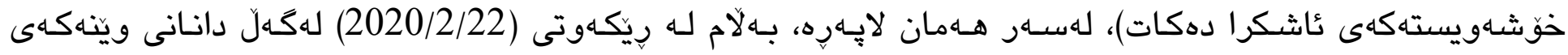

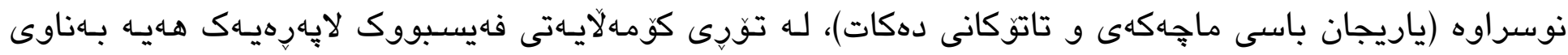

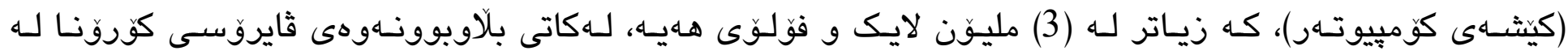

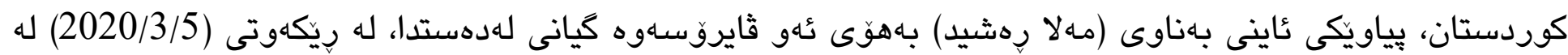

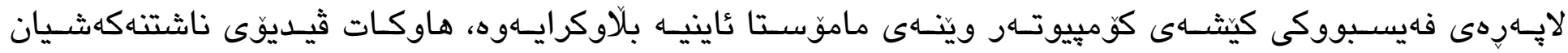
بلأوكردهوه، ئهوهش كاردانهوهى بـهدواى خوّيدا هينا!

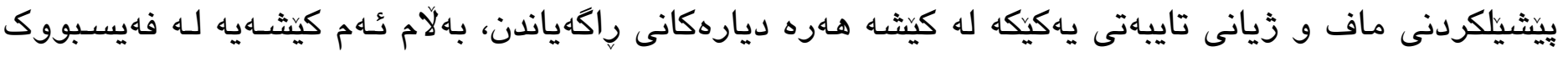

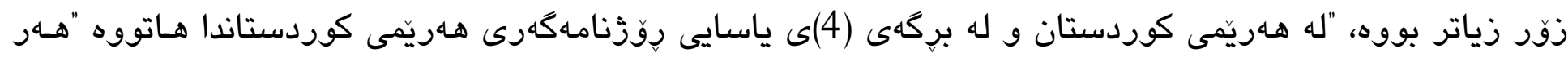

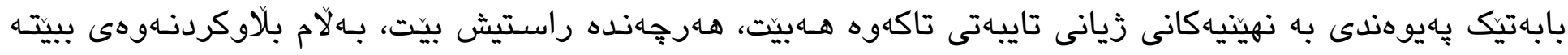

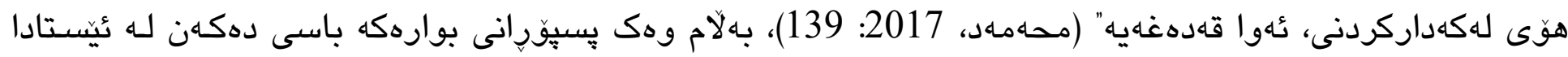

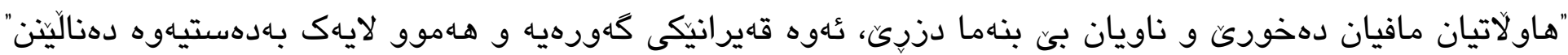

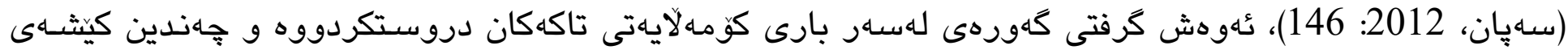
ديكهى كومـهلآياهتى ليكاهوتقوتهوه.

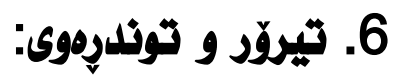

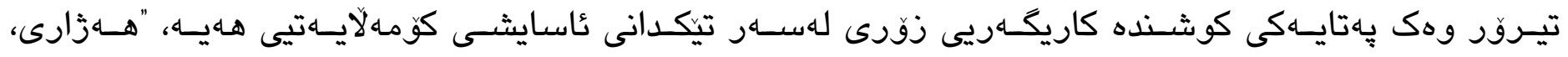

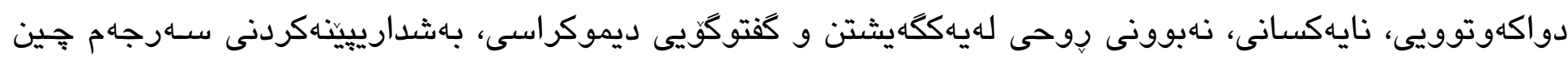

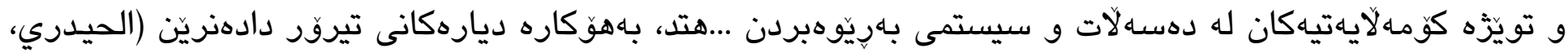

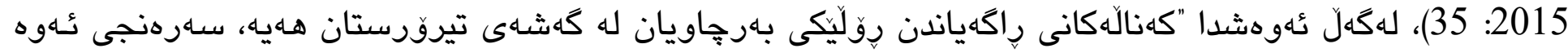

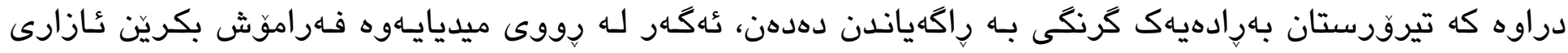

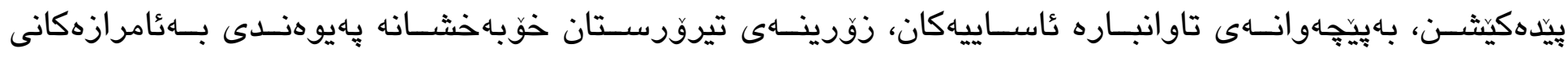

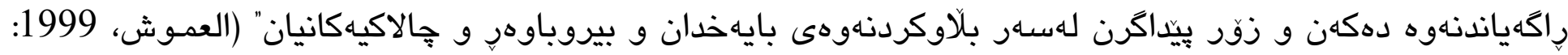

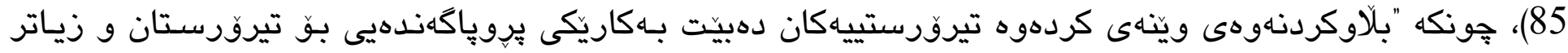
هانيـان دهدات تـا كـردوهى تـر عــنجام بـدهن (عسهلى، 2019، 6)، لههـهانكاتـدا "روّمـالّى كـرده تيرورسـتييهكان و

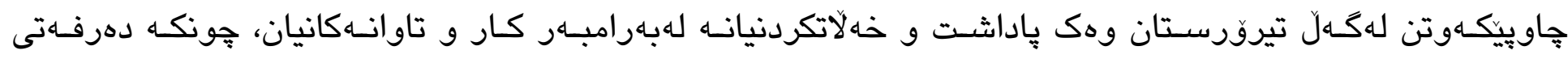
225 


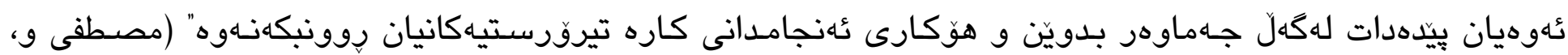
خضر، 2020، 592).

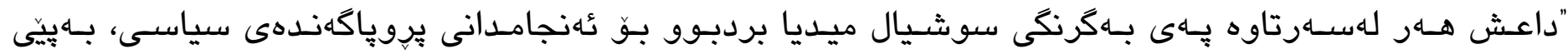

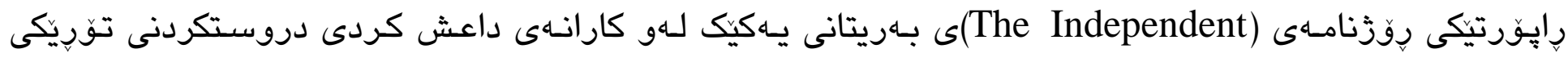

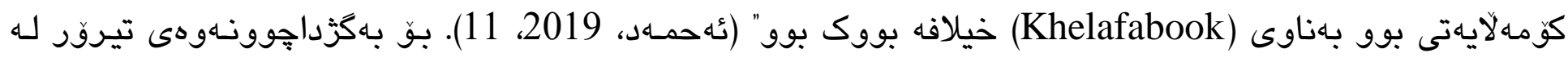

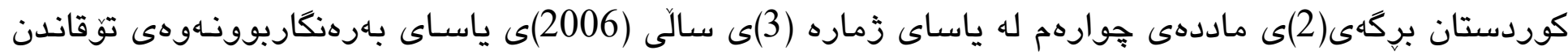

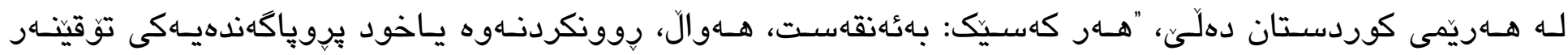

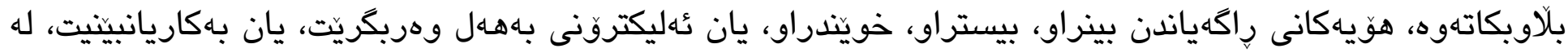

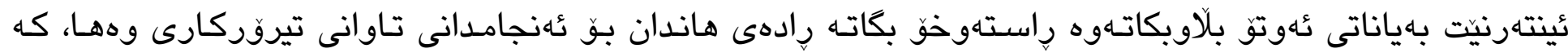

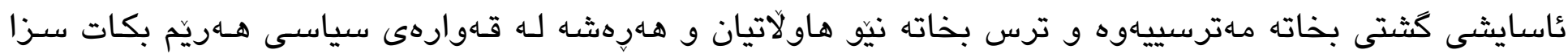

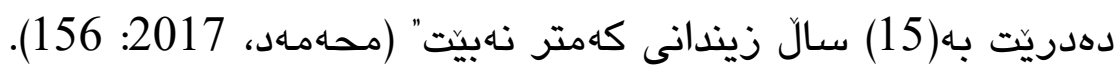

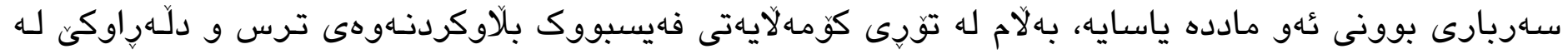

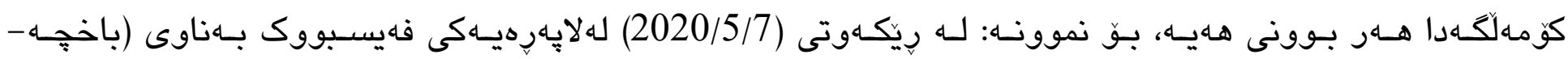

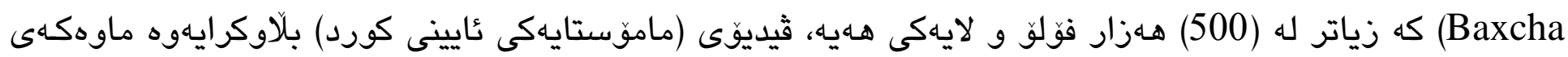

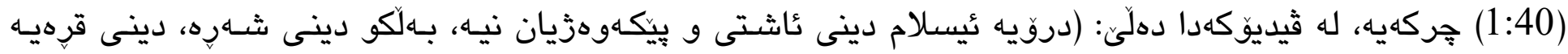

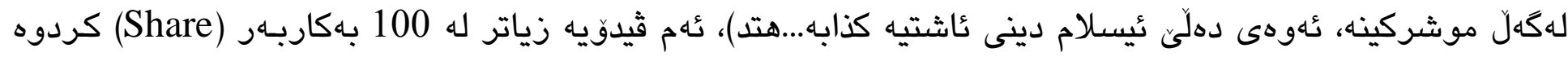

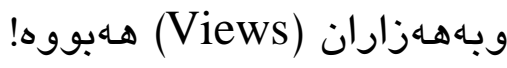

\section{7.}

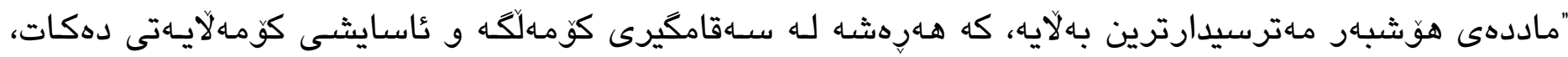
جونكه كاريكارى نهرينى لهسهر تهندروستى جهسته و ئهقلى مروّيى دروست دهكات و دهبيته هوَى بهفيرِّدانى وزه

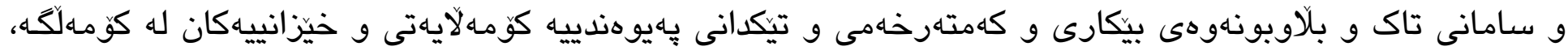

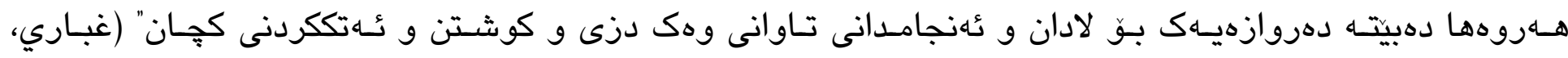
(156:2007

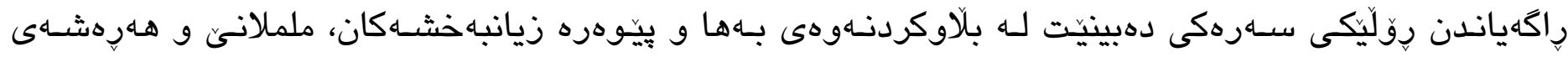

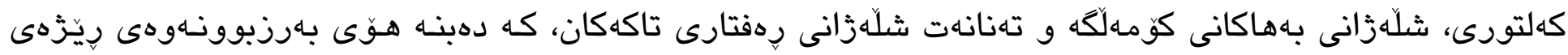
تاوان و لادانهكان بههـموو جوّرهكانيهوه (محهممهد، 2013: 199)، تويَّزينهوهكان ئامازه باهوه دهكهن "ئهو هـهرزهكار 


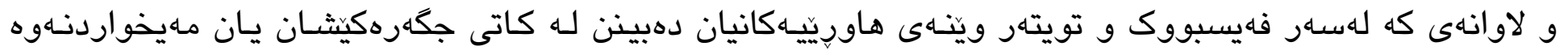

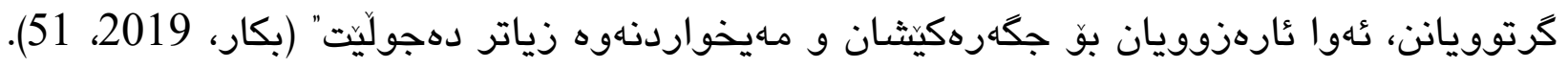

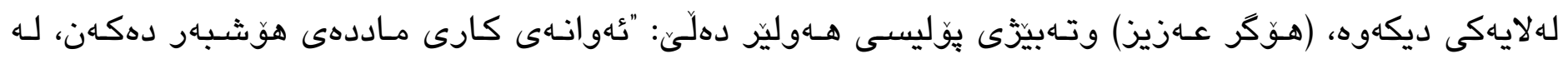

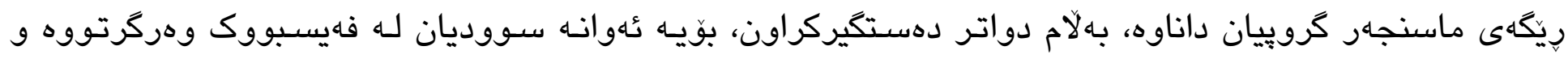

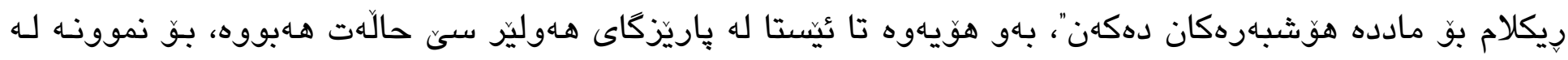

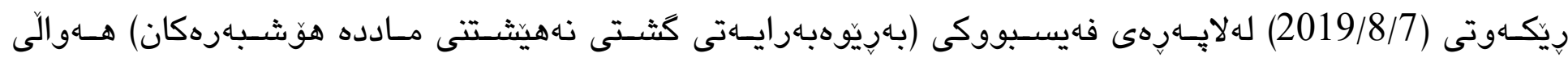

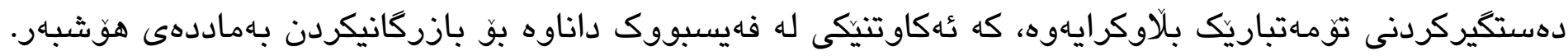

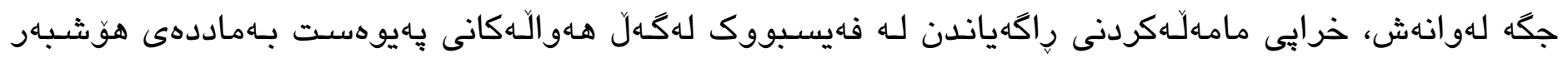

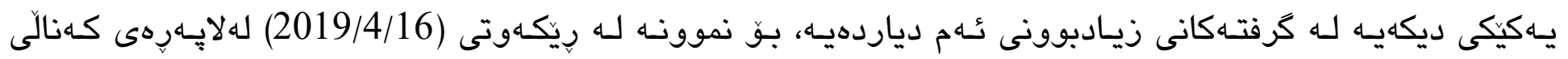

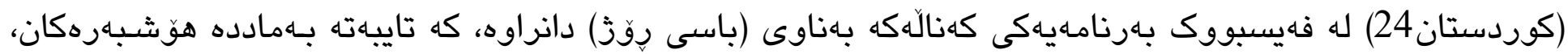

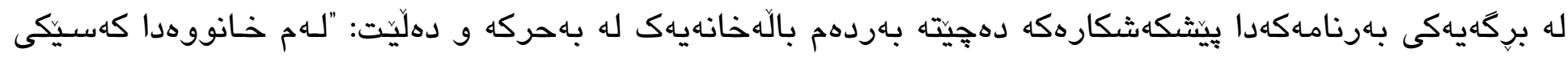

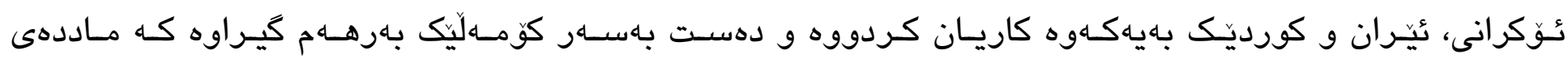

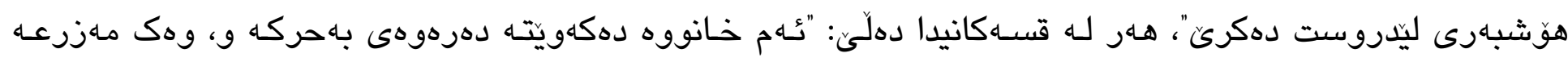

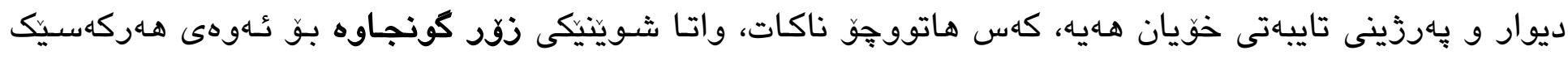

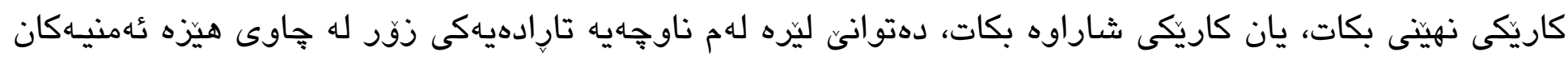

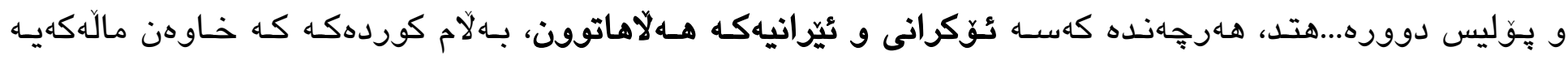

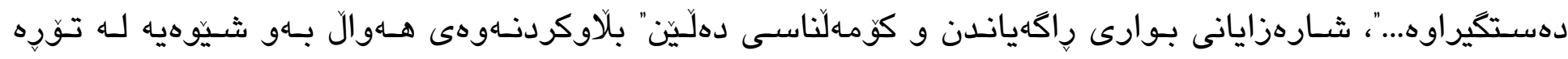

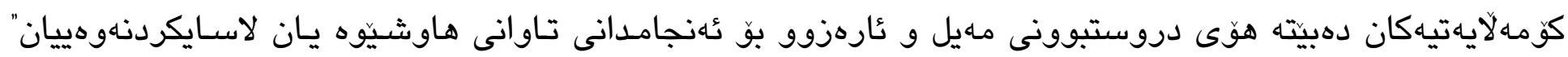

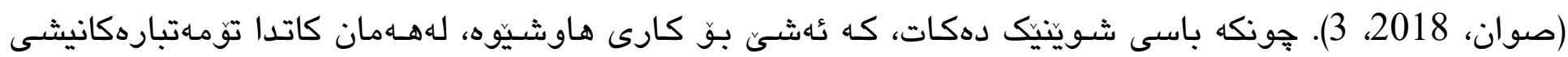
وهك پِالّوان ويناكردووه، كه توانيويانه رِابكهن. 


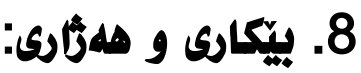

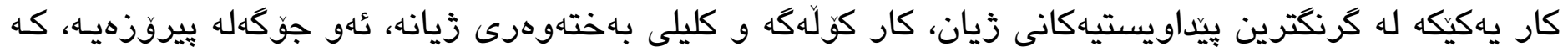

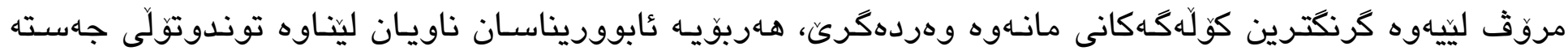

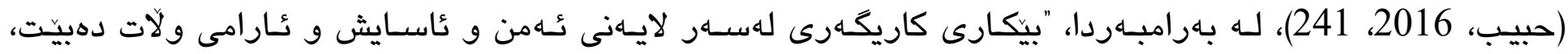

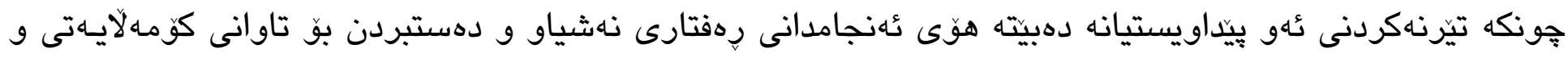

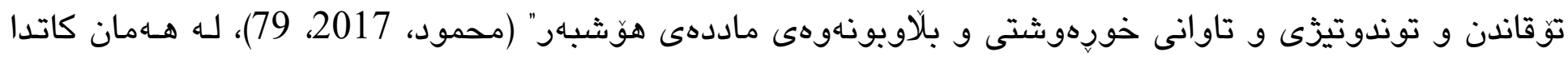

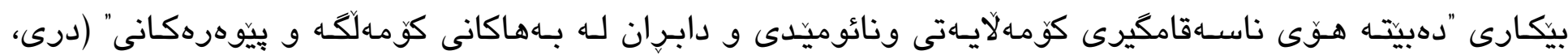

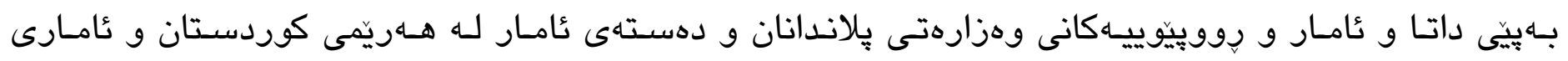

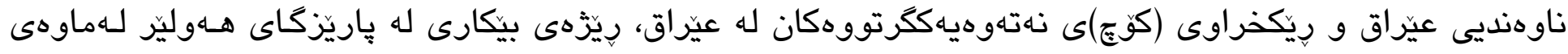

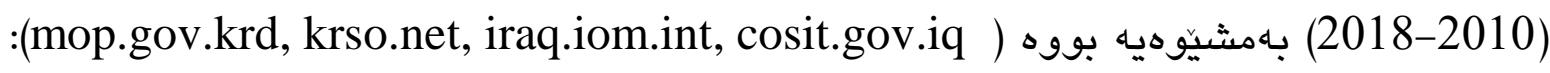
خشتهى (3) ريزهى بيكارى لهماوهى (2010-2018) له بِاريزّكاى هـوليَّر دهخاتهروو

\begin{tabular}{|c|c|c|c|c|c|c|c|c|c|c|}
\hline 2019 & 2018 & 2017 & 2016 & 2015 & 2014 & 2013 & 2012 & 2011 & 2010 & سال \\
\hline- & 10.2 & 9.2 & 13.62 & 13.45 & 5.04 & 5.2 & 7.5 & 6 & 4.0 & بيكارى \\
\hline- & 8.7 & 8.1 & 11.04 & 9.91 & 3.25 & 2.8 & 4.8 & - & 2.7 & نيز \\
\hline- & 16.1 & 20.1 & 22.41 & 28.64 & 15.29 & 12.8 & 22.1 & - & 12.6 & مىي \\
\hline
\end{tabular}

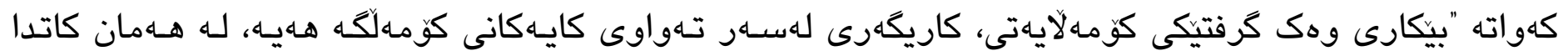

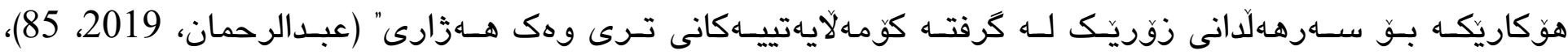

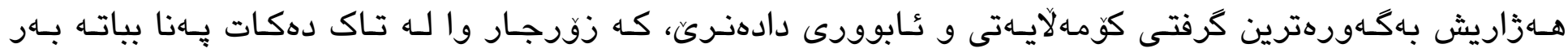

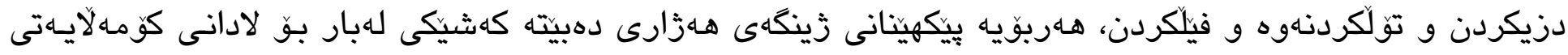
(يوسف، 2016: 288).

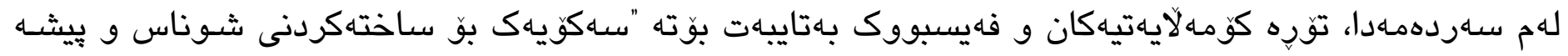

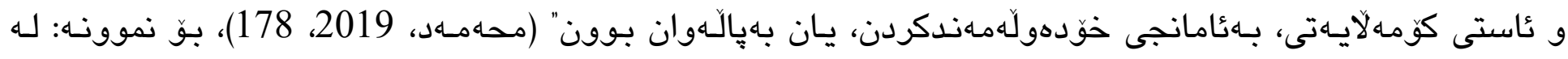

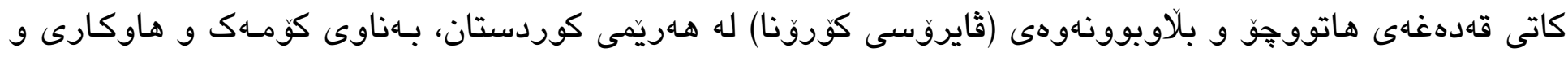

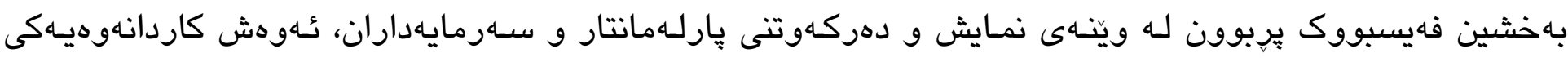




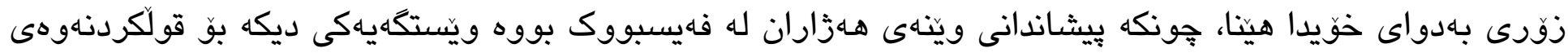
عازارهكانى هـزارى.

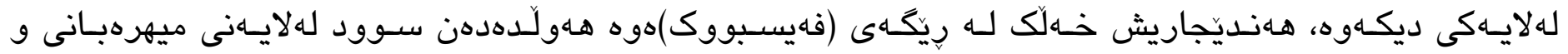

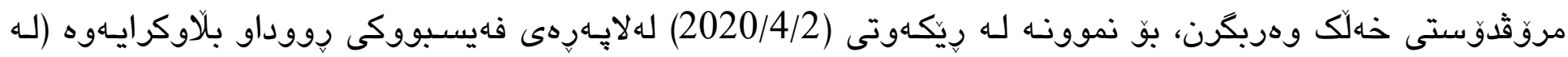

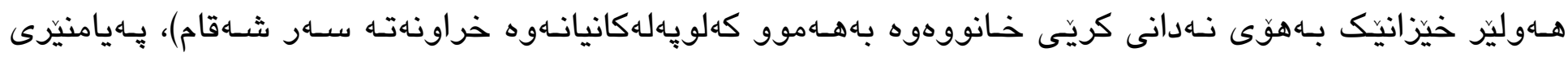

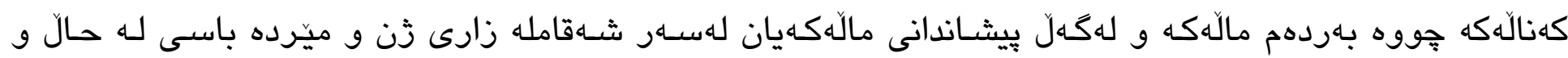

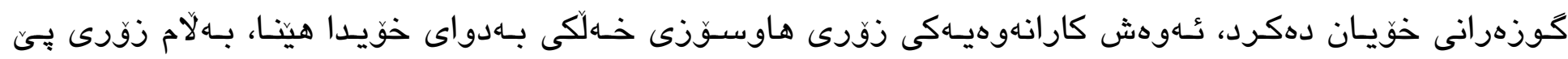

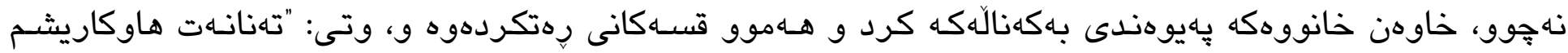

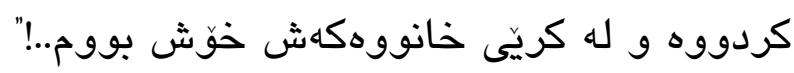

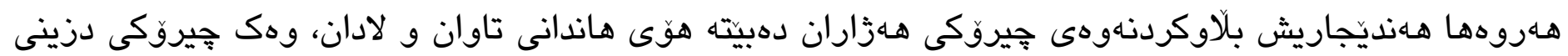

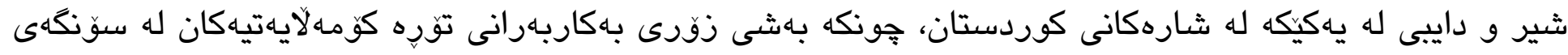

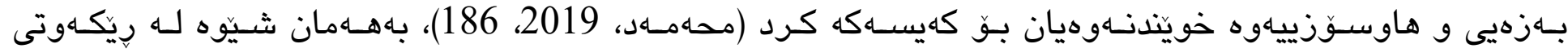

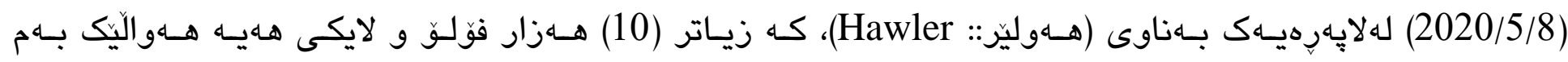

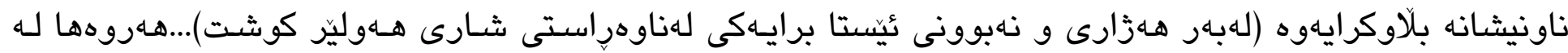

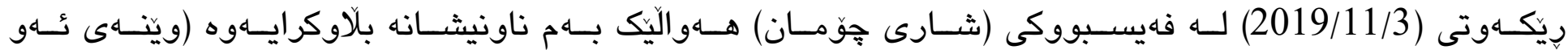

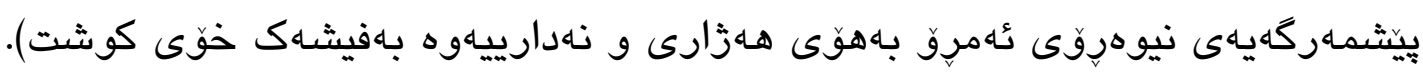

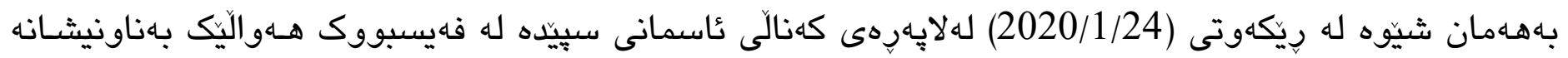

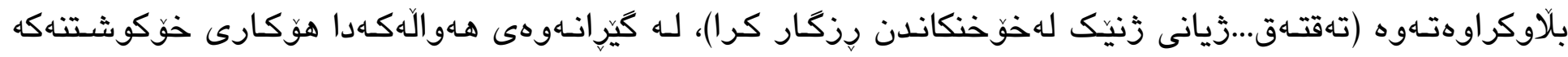

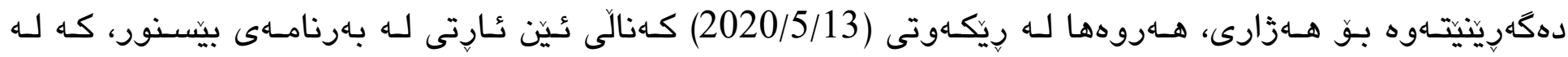

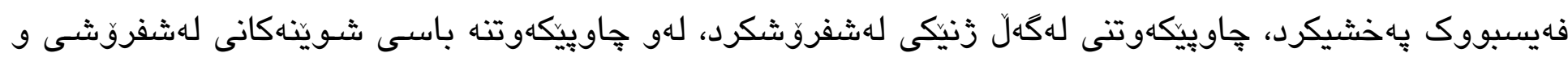

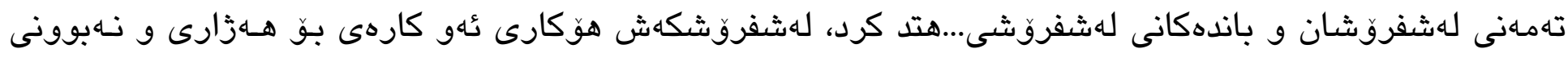

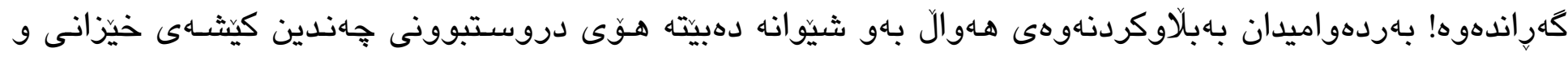

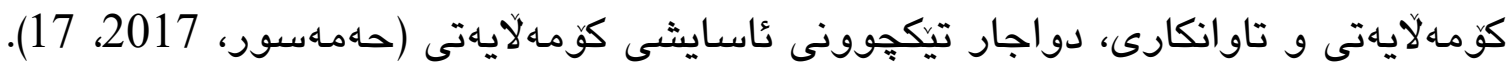




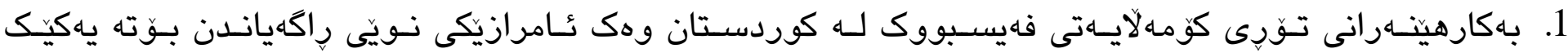

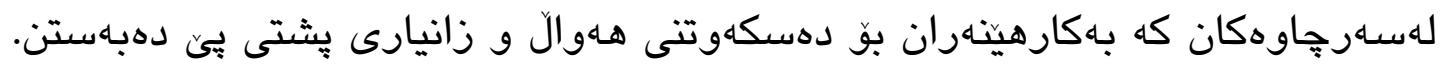

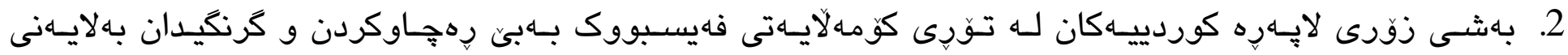

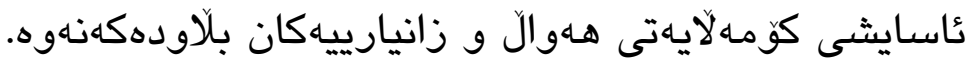

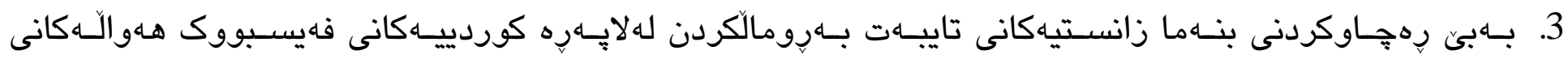

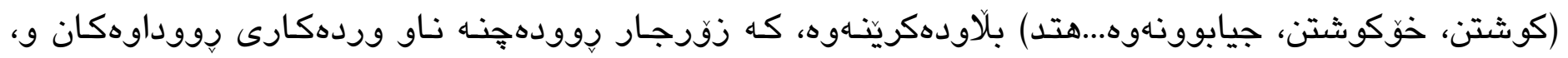
كهانى خوّكوز و تاوانباران وهك بِالَوان وينا دهكرين.

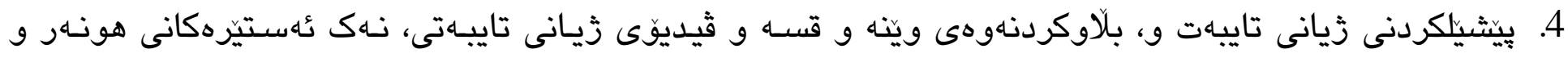

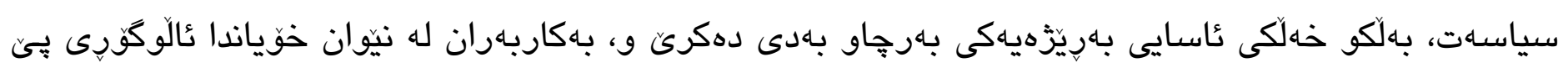
دهكهن.

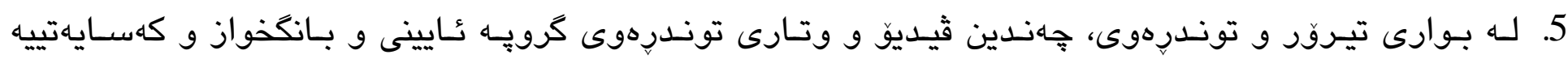

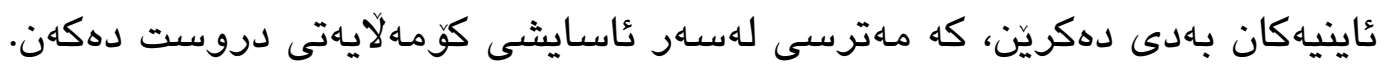

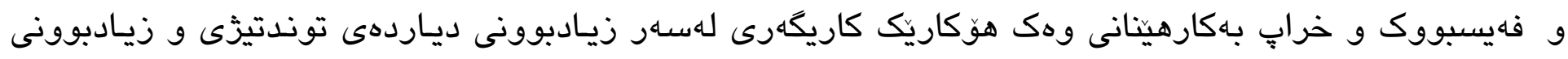
ريّزّهى جيابوونهوهى هاوساهران هـبوروه.

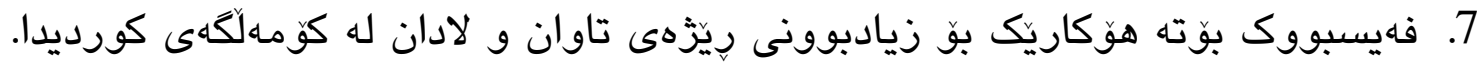

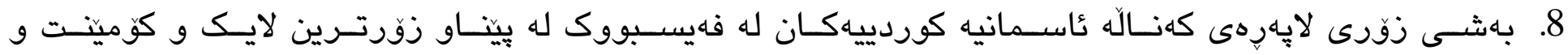

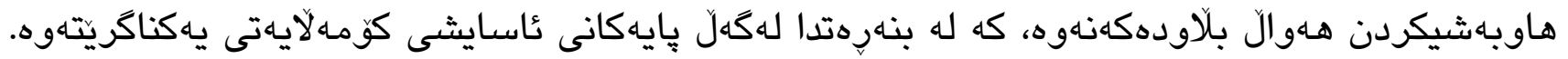

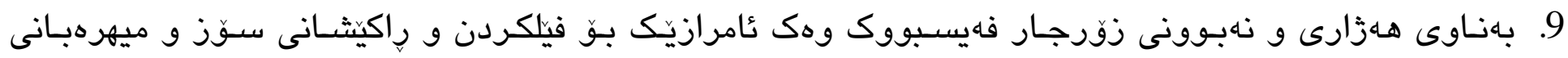
لهلايهن باككارهينّاران بهكارديى.

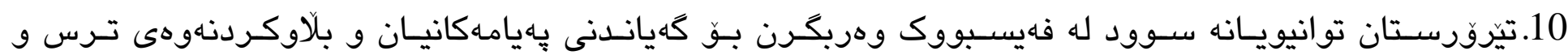
دلّهراوكيَّ له كومهالكَهدا. 


\title{
The Risk of Facebook Social Media Network on Social Security
}

\section{Hemin Amen Jalal Shwani}

Department of Sociology, College of Arts, Salahaddin University, Erbil, Kurdistan Region, Iraq. E-mail: hemin.jalal@mhe-krg.org

\section{Tahir Hasoo Zebari}

Department of Sociology, College of Arts, Salahaddin University, Erbil, Kurdistan Region, Iraq. E-mail: tahir.zebari@su.edu.krd

\begin{abstract}
:
Social security, which is considered as a part of national or state security, has great role in developing and advancing society. In this day and age, as we live in a world of development and technology, social security is under various types of threats and risks in most societies. The Press, through its different channels and means, plays a great role in creating and fostering this risk to destabilize social security. This, then, has necessitated many countries to restrict and curb some media outlets and journalists within legal boundaries.

Accordingly, the emergence of the social media outlets in general, and Facebook, as a new social media network in particular, has increased the afore-mentioned risks and threats on social security.

The aim of this paper is an attempt to find the range of the risk that comes out of Facebook on social security in Kurdistan region in general, and Erbil in particular.
\end{abstract}

Key Words: Social Media, Facebook, Risk, Social Security. 


\section{سلورجاومكاز:}

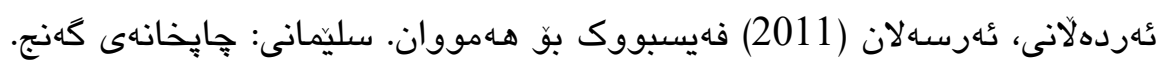

بكار، عبدالكريم (2019) مندالّكانمان و تورِه كوّمهلايهتييهكان. وهركَيِّانى: بههجهت جهميل حامد. سليمانى: ناوهندى راكهياندنى ئارا.

جهمال، نهوزاد (2019) فهلسهفهى و فهيسبووك يان فهلسهفهى فهيسبووك دياردهناسى بوونيكى ئهنديثـاهي. سليمانى: ناوهندى رِههاند.

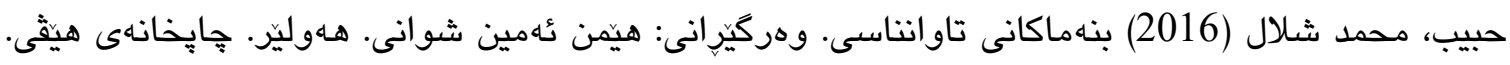

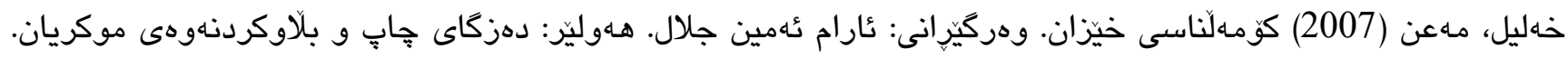

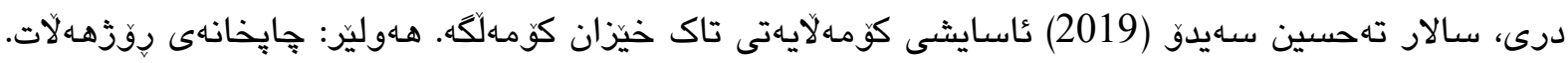

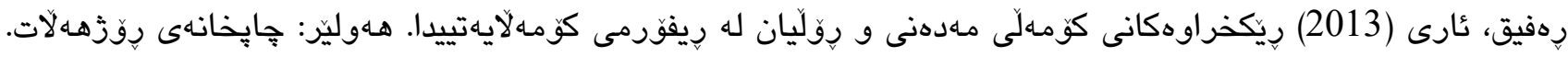

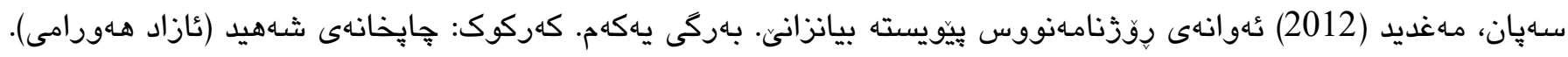
شالينى، ئهمـهد (2018) ئينتهرنيت 101. بهبئ ئامازّكردن بهشوين و ناونيشانى جايكردن.

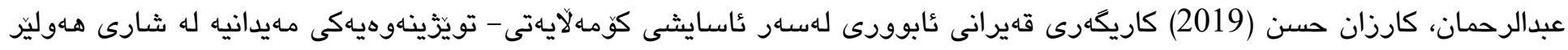

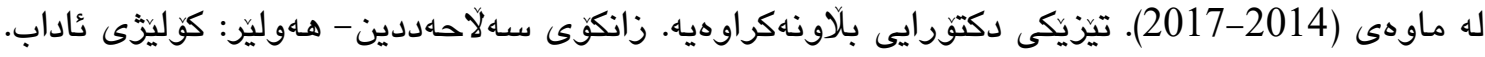

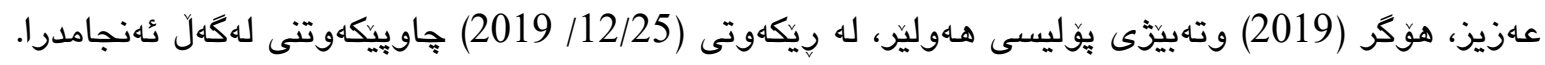




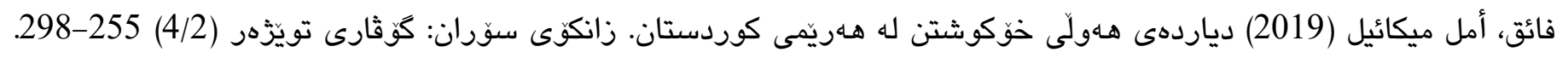

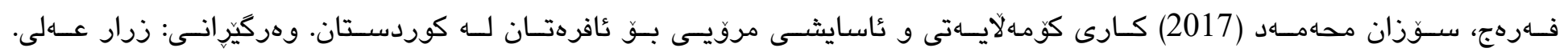
سليمانى:جإِخانهى كهمال.

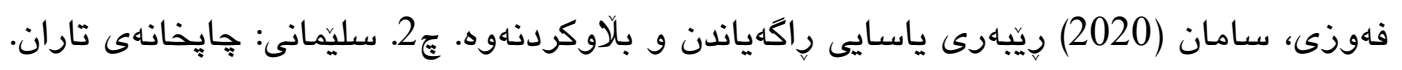

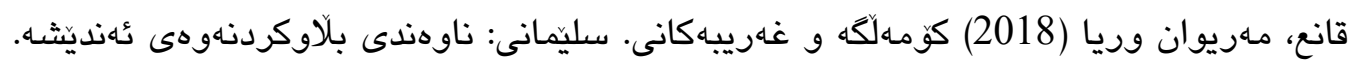

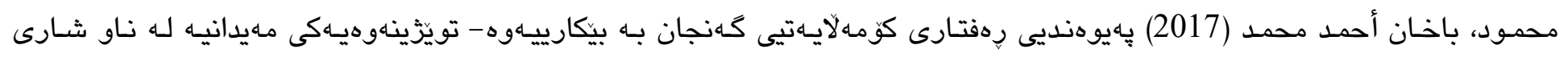
سليمانى. نامهيهكى ماستهرى بلاونهكراوه. سليَمانى: زانكوّى سليّمانى. كوَليَّى زانسته مروّثايهتيهكان.

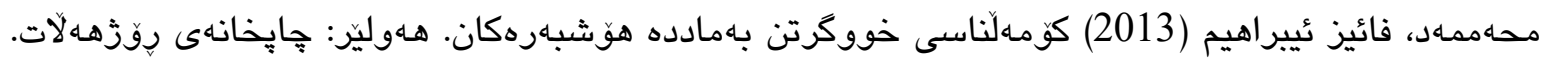
محهمهد، كارزان (2017) رِوّزنامهنووس و تاوانهكانى رِاكهياندن. سليمانى: جإِخانهى ئاسيا.

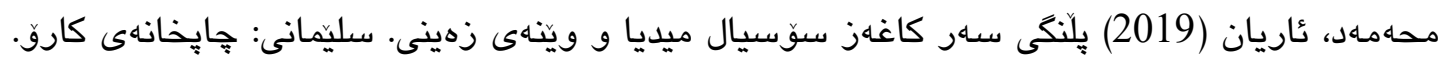

مصطفى، روستم صابر (2017) كاريكهرى فهيسبووك لهسهر يهيوهندييه كومهلاّيهتييهكان لاى قوتابيانى زانكوى سهلاحهدين-هـوليّر. نامهيهكى ماستهره بلاّونهكراوهتهوه. هـوليرّ: زانكوَى سهلاحهدين- أربيل. كوَليَّى عئدهبيات. 


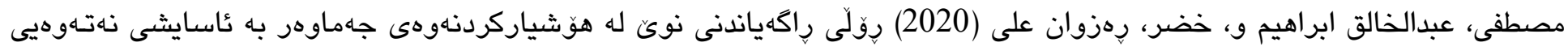

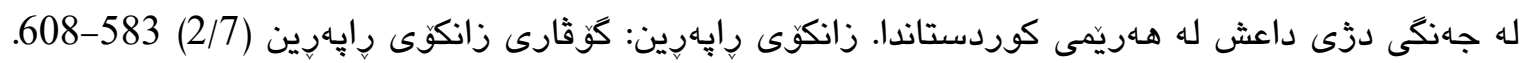

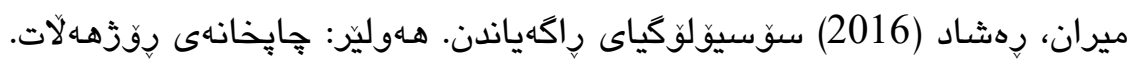

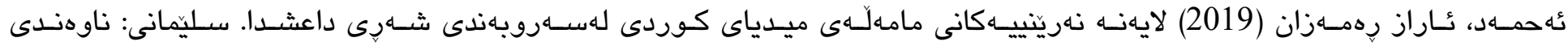

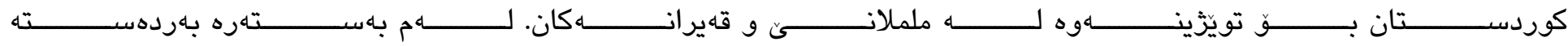
(2020/5/5/5://www.kurdistanc.com/Terror/details.aspx?jimare=3193)

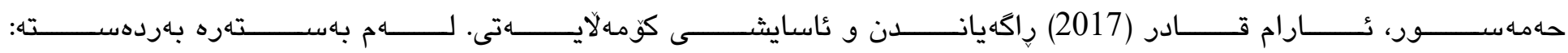
(2020/5/3) رِيكّوتى سهردان (https://www.xendan.org/detailwtar.aspx?jimare=840\&nuser=1245)

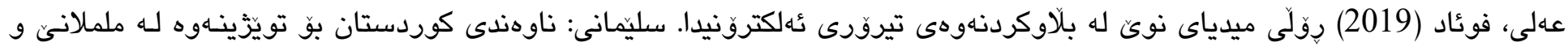

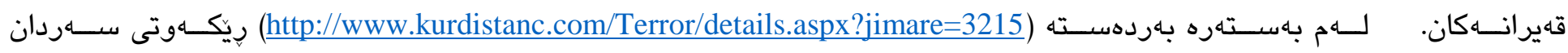
.(2020/5/5)

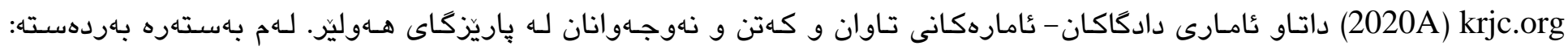
(2020/4/15) رِيكّوتى سـردان (http://www.krjc.org/Default.aspx?page=category\&c=dad2018)

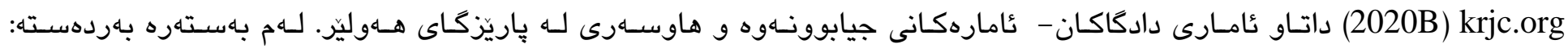
(2020/4/18) ريككهوتى سهردان (http://www.krjc.org/Default.aspx?page=category\&c=dad2010)

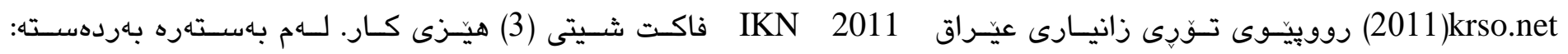
(http://www.krso.net/files/articles/030516055254.pdf)

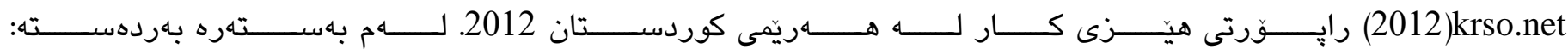
(http://www.krso.net/files/articles/230714011211.pdf) 


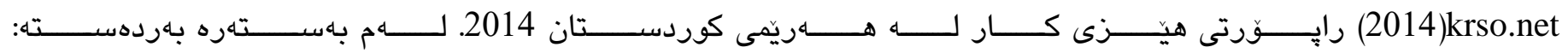
(2020/5/8): بيكهوتى سهردان (2htp://www.krso.net/files/articles/080816025529.pdf)

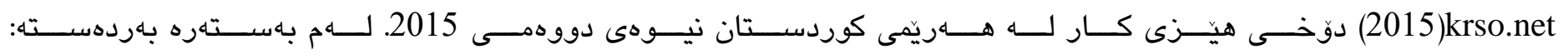
(2020/4/18) بيككوتى سهردان: (20ttp://www.krso.net/files/articles/280517035934.pdf)

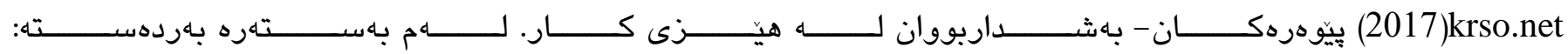
(http://www.krso.net/Default.aspx?page=article\&id=893\&l=3\&\#krso2)

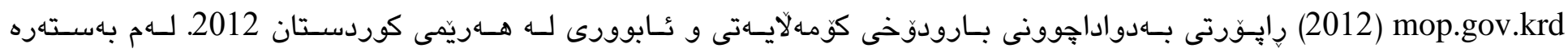

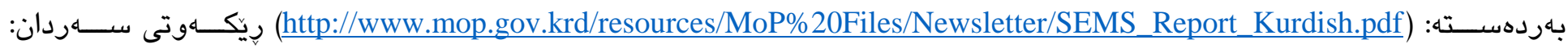
.$(2020 / 4 / 15)$

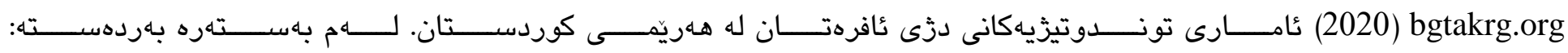

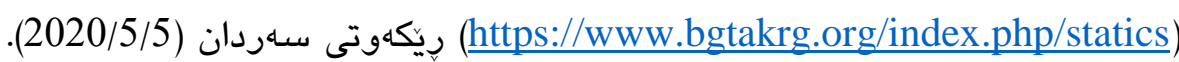

أبوضاحي، لينا خالد (2018) اتجاهات طلبة الجامعات في محافظات غزة نحو أخبار الجريمة في المواقع الإخباريـة الفلسطينية و علاقتها بخصائصهم الاجتماعية، رسالة ماجستير غير منشورة. فلسطين: الجامعة الإسلامية - غزة. كلية الاداب.

بدوي، عمار توفيق أحمد (2014) أثر وسائل التواصل الحديثة على الدعوة الفيس بوك نمونجا. فلسطين: جامعة النجاح الوطنيـة. المؤتمر

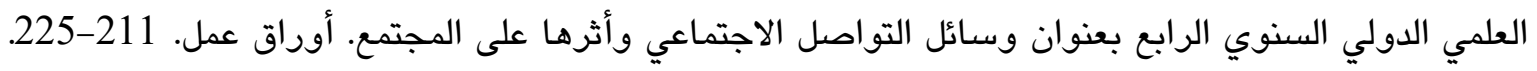

الحيدري، إبراهيم (2015) سوسيولوجيا العنف و الإرهاب. بيروت: دار الساقي.

دغريري، علي بن حمد بن أحمد (2017) إدمان شبكات التواصل الاجتمـاعي وعلاقته بالشـعور بالوحدة النفسية لدي المراهقين. فلسطين:

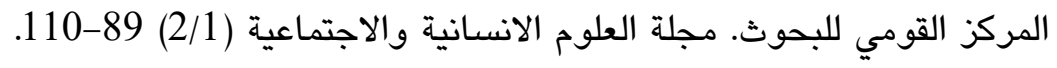
235 
سمير، فارح (2009) ظاهرة العود للإدمان على المخدرات والتفكك الأسري. رسالة ماجستير غير منشورة. الجزائر: جامعـة بن يوسف بن خدة ـ كلية العلوم الاجتماعية و الإنسانية.

الصفار، حسن موسى (2008) المؤسسات الأهلية و حماية الأمن الاجتماعي. القطيف: مكتبة الملك فهد الوطنية.

العزاوي، مظفر مندوب (1983) التلفزيون و دوره التربوي في حياه الطفل العراتي. بغداد: دار الحرية للطباعة.

العموش، أحمد فلاح (1999) أسباب انتشار ظاهرة الإرهاب. أكاديمية نايف العربية للعلوم الأمنية: مجلة مكافحة الإرهاب (240): 61-110. غباري، محمد سلامة محمد (2007) الإدمان خطر يهدد الأمن الاجتماعي. الإسكندرية: دار الوفاء لدنيا الطباعة و النشر.

لكحل، حميمة و، زايدى، ربيحة (2017) أثر إستخدام مواقع التواصل الاجتماعي في العلاقات الأسـرية الفيس بوك نموذجـا-دراسـة ميدانيـة

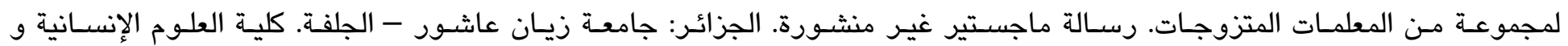
الاجتماعية.

المدني، نبيل (2011) الأمن الاجتماعي بنظرة فلسطينية. مجلة لارك للفلسفة واللسانيات و العلوم الاجتماعية. العراق: جامعة واسـط. (3/15): .128-119 المري، على بن ربيع (2006) التفكك الأسري و خطره على الأمن الاجتماعي. مجلة (الامن و الحياة) الرياض: (305). هرزاني، نوري (2005) الإعلام و الجريمة. هـهوليرّ: مطبعة جامعة صلاح الدين/اربيل. يوسف، مصطفى (2016) علم الاجتماع الإعلامي. عمان: دار و مكتبة الحامد للنشر و التوزيح.

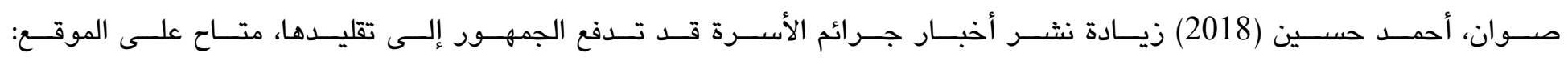
(https://www.elwatannews.com/news/details/3682609) 


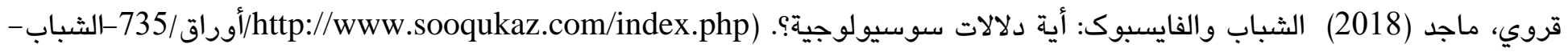

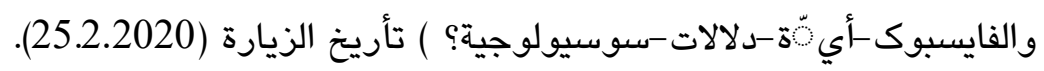

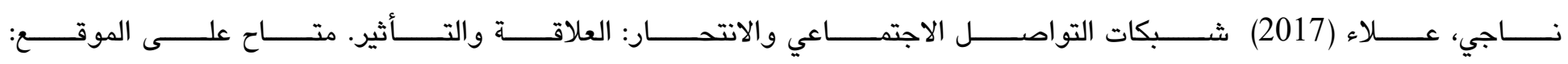
(https://m.annabaa.org/arabic/studies/11675)

cosit.gov.iq تأريخ الزيارة (http://cosit.gov.iq/AAS2017/Annual\%20Abstract\%20of\%20Statistic\%20_2017.pdf)

Sustainable Development.un.org (https://sustainabledevelopment.un.org/content/documents/23321IraqVNR2019Final11June2019WOC.pd)

Buzzetto, Nicole A. -More (2012) Social Networking in Undergraduate Education. USA: Informing Science Institute. Interdisciplinary Journal of Information, Knowledge, and Management Special Section on Social Networking, Teaching, and Learning (7): 63-90.

Ellison, Nicole. B, Steinfield, Charles, \& Lampe, Cliff (2007) The Benefits of Facebook “Friends": Social Capital and College Students' Use of Online Social Network Sites. United Kingdom: Oxford University Journal of Computer-Mediated Communication, (12/4): 1143-1168.

Gordon, Steven (2017) Online Communities as Agents of Change and Social Movements, Chapter: The Impact of Social Media on Social Movements: The Case of Anti-Consumption. Reading: Ergun, Sinem \& Erdogmus, Irem Eren. United States of America: Publisher: IGI-Global.

Niu, Lian (2019) Using Facebook for academic purposes: Current literature and directions for future research. Journal of Educational Computing Research, 56(8), 1384-1406.

Nyoni, Phillip and Velempini, Mthulisi (2018) Privacy and user awareness on Facebook. the Academy of Science of South Africa: South African Journal of Science .114(5/6): 27-31. 
Alhabash, Saleem and, Ma, Mengyan (2017) A Tale of Four Platforms: Motivations and Uses of Facebook, Twitter, Instagram, and Snapchat Among College Students? United States: Minneapolis. Conference Association for Education in Journalism and Mass Communication Conference (AEJMC). Social Media + Society journal. Available From: (https://journals.sagepub.com/doi/10.1177/2056305117691544). Accessed 30.3.2020.

Boyd, Joshua (2019) The History of Facebook: From BASIC to Global Giant. Available From: (https://www.brandwatch.com/blog/history-of-facebook/). Accessed 25.3.2020.

Internet World Stats (2020a) World Internet Usage and Population. Online. Available From: (https://www.internetworldstats.com/stats.htm). Accessed 15.4.2020.

Internet World Stats (2020b) Facebook Users in the Africa. Online. Available From: (https://www.internetworldstats.com/stats1.htm). Accessed 15.4.2020.

Internet World Stats (2020c) Facebook Users in the Latin America. Online. Available From: (https://www.internetworldstats.com/stats2.htm). Accessed 15.4.2020.

Internet World Stats (2020d) Facebook Users in the Asia. Online. Available From: (https://www.internetworldstats.com/stats3.htm). Accessed 15.4.2020.

Internet World Stats (2020e) Facebook Users in the Europe. Online. Available From: (https://www.internetworldstats.com/stats4.htm). Accessed 15.4.2020.

Internet World Stats (2020f) Facebook Users in the Middle East. Online. Available From: (https://www.internetworldstats.com/stats5.htm). Accessed 15.4.2020.

Internet World Stats (2020g) Facebook Users in the North America. Online. Available From: (https://www.internetworldstats.com/stats14.htm). Accessed 15.4.2020.

Internet World Stats (2020h) Facebook Users in the Australia. Online. Available From: (https://www.internetworldstats.com/stats6.htm). Accessed 15.4.2020.

iraq.iom.int (2018) DEMOGRAPHIC SURVEY-Kurdistan Region of Iraq. Online. Available From: (https://iraq.iom.int/demographic-survey-kurdistan-region-iraq) Accessed 27.4.2020. 
Napoleon Cat (2020) Facebook Users in the Iraq. Online. Available From: (https://napoleoncat.com/stats/facebook-users-iniraq/2020/03) Accessed 17.4.2020.

World Health Organization (2020) Suicide. Online. Available From: (https://www.who.int/news-room/factsheets/detail/suicide) Accessed 3.5.2020. 